\title{
Social status in late medieval and early modern Brittany: insights from stable isotope analysis
}

\author{
Rozenn Colleter $^{1,2} \cdot$ Benoît Clavel $^{3} \cdot$ Anita Pietrzak $^{4} \cdot$ Sylvie Duchesne ${ }^{1,2}$. \\ Ludovic Schmitt ${ }^{1,5}$ • Michael P. Richards ${ }^{6}$ • Norbert Telmon ${ }^{2,7} \cdot$ Éric Crubézy $^{2}$ • \\ Klervia Jaouen ${ }^{4}$
}

Received: 7 July 2017 / Accepted: 28 September 2017 /Published online: 1 December 2017

(C) The Author(s) 2017. This article is an open access publication

\begin{abstract}
We document for the first time the diet of a privileged French population from Brittany, a region that was the center of battles between the Kingdoms of England and France until the end of the fifteenth century. We present here the results of stable isotope analyses of carbon, nitrogen, and sulfur of human and animal bone and tooth collagen for a late medieval to early modern Breton population. The isotopic values observed for the Dominican convent of Rennes, Brittany, are very similar to those reported for medieval archaeological populations in Great Britain, namely they have enriched $\delta^{15} \mathrm{~N}$ values combined with almost entirely terrestrial carbon signals. We discuss the consumption of young animals
\end{abstract}

Electronic supplementary material The online version of this article (https://doi.org/10.1007/s12520-017-0547-9) contains supplementary material, which is available to authorized users.

Rozenn Colleter rozenn.colleter@inrap.fr

$\triangle$ Klervia Jaouen

klervia_jaouen@eva.mpg.de

1 Institut National de Recherches Archéologiques Préventives (INRAP), 37 Rue du Bignon, Cesson-Sevigne, France

2 AMIS, CNRS, UMR 5288, Université Paul Sabatier, 37 Allée Jules Guesde, Toulouse, France

3 MNHN, CNRS, UMR 7209, Sorbonne Université, 55 rue Buffon, Paris, France

4 Department of Human Evolution, Max Planck Institute for Evolutionary Anthropology, Deutscher Platz 6, Leipzig, Germany

5 Réseau IN-HOPPE, Institut National d'Études Démographiques, 133 Boulevard Davout, Paris, France

6 Department of Archaeology, Simon Fraser University, 8888 University Dr., Burnaby, BC V5A 1S6, Canada

7 CHU Toulouse Rangueil, 1 Avenue du Professeur Jean Poulhès, Toulouse, France in a diet made up of terrestrial, marine, and freshwater resources. We report dietary differences between socioeconomic groups and gender, with women and nobles (male and female) showing patterns consistent with high animal product consumption and lower mobility. The $\mathrm{S}$ isotope ratios of both humans and fauna are very homogeneous and generally have coastal $\delta^{34} \mathrm{~S}$ values. The convent is known to have been an interregional pilgrimage site during the early modern period, but the isotope values indicate that the identified migrants were not pilgrims. Stable isotope analysis therefore complements the available historical information on human diets and mobility.

Keywords Post medieval $\cdot$ Modern period $\cdot$ Brittany $\cdot$ Diet . Sulfur isotopes $\cdot$ Mobility $\cdot$ Convent

\section{Introduction}

Stable isotope studies of late medieval and early modern Western European populations

Isotopic analyses are widely used to unravel dietary differences between social status in late medieval and early modern times in several European regions (Polet and Katzenberg 2003; Müldner and Richards 2005, 2007; Fornaciari 2008, Kjellström et al. 2009; Mundee 2010; Yoder 2012; Lubritto et al. 2013; Quintelier et al. 2014; Lamb et al. 2014; Alexander et al. 2015; Olsen et al. 2016, van der Sluis et al. 2016). In France, the diet of urban poor individuals was documented (Bocherens 1991; Herrscher et al. 2001, 2003, 2004), but differences between socio-economic groups have yet to be investigated. In other Western European regions, high $\delta^{15} \mathrm{~N}$ values and low $\delta^{13} \mathrm{C}$ values of wealthy populations were generally reported, especially in Great Britain and Scandinavian 
countries. The high $\delta^{15} \mathrm{~N}$ values of European wealthy populations cannot be explained by the sole consumption of herbivore meat. The diet of ecclesiastics and privileged European populations therefore probably included the consumption of food with a higher trophic level such as omnivore meat (pig, fowl) or freshwater fish (Müldner and Richards 2005). The later hypothesis is generally preferred because Catholic fasting rules forbade the consumption of meat for one third of the year (Müldner and Richards 2005, 2007; Yoder 2012). Nevertheless, the diversity of animal protein sources in medieval and modern period human diets (marine, migratory and freshwater fish, herbivore or omnivore meat, eggs, and to a lesser extent, dairy products) complicates the quantification of each food category. $\mathrm{S}$ isotope analyses are being utilized more often to investigate this issue, as they can trace the consumption of marine, terrestrial and sometimes freshwater food (Nehlich 2015; Sayle et al. 2016). However, in coastal regions, terrestrial and aquatic food products have similar $\mathrm{S}$ isotope signature (Lamb et al. 2012; Nehlich 2015). In this context, $\mathrm{S}$ isotopes are usually utilized to identify migrants coming from inland regions (Richards et al. 2003).

\section{Dietary habits in Brittany from the thirteenth to the eighteenth centuries}

Between the thirteenth and the eighteenth centuries, Brittany is going through a wealthy period, first as an autonomous Duchy (medieval period) and then as a French Province (early modern period). This golden age of Brittany is however interspersed by military conflicts and epidemics. Little is known on the respective influence of the increased over time wealth and temporary difficulties on Bretons' diets. In medieval and early modern times, dietary habits of Bretons were supposed to be very similar to those of their European contemporaries and were mainly influenced by their socio-economic status. It is known that nobles and well-off individuals included a high proportion of meat into their diet (Croix 1981; Quellier 2007). Peasant diets were mostly cereal-based (wheat, rye, barley, buckwheat, and oats; Croix, 1993) while urban laborers had regular access to meat (Croix 1981; Quellier 2007). In wealthy and urban populations, fish usually replaced meat on fasting days (Quellier 2007). In Rennes, the consumption of fish can be considered a social marker: nobles and elites favored a diversity of species, including marine, migratory, and freshwater animals (Clavel 2010), whereas urban commoners complained of the monotony of cod consumption (Croix 1981).

\section{Aim of the study}

The Dominican convent of Rennes offers the unique opportunity to study dietary differences between socio-economic groups which were buried there (parliamentary nobility, ecclesiastics, soldiers, and commoners) in one of the three capital cities of Brittany (Fig. 1; Colleter et al. 2016; Le Cloirec 2016). Moreover, the presence of a garbage dump contemporaneous and adjacent to the convent allows the direct study of the animals that were eaten by the local population. Using stable isotopes of carbon, nitrogen, and sulfur, we here investigate if the intense fish and meat consumption in urban Breton diets can be documented and if social status differences can be distinguished despite the substantial animal product consumption of the whole population. We present isotope data for human ( 85 individuals) and animal (34 terrestrial animals and fish) material collected during the rescue excavations at the Dominican convent of Rennes, France (Fig. 1; 2013-2014, Le Cloirec 2016) as well as the sixteenth c. garbage dump of the Sainte-Anne Hospital situated nearby (1999; Clavel 2010). These data provide further evidence for an overall substantial consumption of animal products in the whole population, however nuanced by social status differences. We identified a mixed subsistence strategy of the privileged individuals, including marine and terrestrial foods, albeit dominated by herbivore and omnivore meat. The latter may be confused isotopically with proteins from freshwater or migratory resources (likely eels). We find that the relative amount of protein in the diet of Breton nobles is similar to those observed for other European courts (Fornaciari 2008; Lamb et al. 2014; Jiménez-Brobeil et al. 2016). Taking into account the historical context, we also discuss the meaning of the increase of $\delta^{15} \mathrm{~N}$ values of ecclesiastics' teeth and bones between the late medieval and early modern periods and the higher $\delta^{15} \mathrm{~N}$ values for females for both tooth and bone collagens. Finally, the documentation of $\delta^{34} \mathrm{~S}$ values reveals a local origin of the parliamentary nobles and the women, whereas the soldiers all came from inland regions.

\section{Material}

\section{Human material}

Six hundred and five burials corresponding to the medieval to early modern periods were the subject of a detailed study (Le Cloirec 2016). Three phases of burial are differentiated on the site (Le Cloirec 2016; Fig. 2). The first phase (thirteenth c. phase 1) predates the construction of the convent, and includes 12 subjects ( 2 children and adolescents and 10 adults including $8 \mathrm{men}$ ). The presence of these skeletons in a residential neighborhood out of a cemetery remains unexplained. The second (phase 2) and the third phase (phase 3) are contemporaneous to the convent. The phase 2 goes from the end of the fourteenth century to the sixteenth century with 137 (22 immature individuals and 115 adults), and the phase 3 covers the seventeenth and eighteenth centuries and therefore corresponds to the modern period (73 immature individuals and 


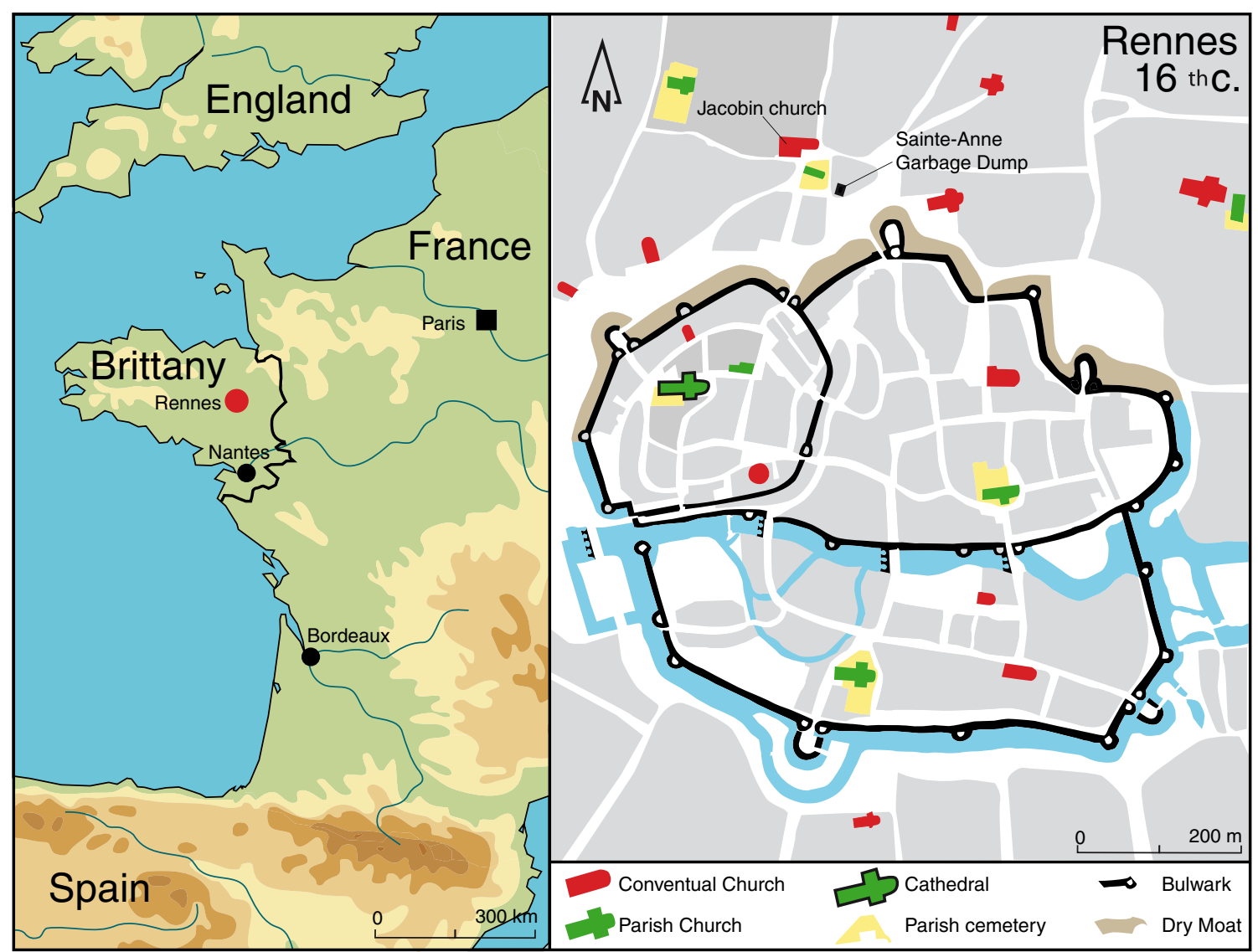

Fig. 1 Location of the site. On the left: The historical border of Brittany in the fifteenth century. On the right: Rennes in the sixteenth century. The locations of the convent and the garbage dump are outside of the walls

383 adults) (Table 1). Between the end of the fourteenth and the eighteenth century, the settlement was an important place of pilgrimage - because of the presence of a "miraculous painting" in the convent—and burial, especially for the parliamentary nobility (Croix 1981; Bordeaux 1992; Colleter et al. 2016).

Historical archives and previous archaeological works document the existence of different socio-economic groups buried in the Dominican convent of Rennes (Table S1). For instance, the existence of privileged burials (church choir, adjoining chapels), characterized by ostentatious attributes (marking, situation, etc.), is a good indicator of the establishment of a favored socio-economic group in the Dominican convent (Croix 1981). We therefore attributed a socioeconomic group to the different individuals depending on their burial location. The majority (319/605 subjects, i.e., $53 \%$ ) correspond to the abovementioned privileged status (A group). Within this group, 26 aristocrats are identified based on specific funeral practices: embalming and/or lead coffins (A' group; Colleter et al. 2016). A second group is identified as less favored as the A group (B group) and includes 188 subjects buried in the nave of the church, in the cloister garden, and in the immediate exteriors of the convent $(188 / 605$, i.e., $31 \%$ of subjects). The individuals from the nave ( $\mathrm{B}^{\prime}$ group) might have a higher status than the others since they are buried within the convent walls. The west yard also contains an ossuary (group B"). In addition, 66 individuals from the chapter house are likely to be Dominican ecclesiastics (C group) (66/605, i.e., 11\%). Finally, 32 subjects with blade injuries (and some lethal) were found in mass graves; all men and death between 15 and 50 years old were probably soldiers (D group) (32/605, i.e., 5\%; Table 1). In total, 85 individuals were sampled ( 81 bones, 54 teeth). The distribution of the individuals sampled by socio-economic group, phase, age of death, and sex are given in the Table 1.

\section{Faunal remains}

The faunal remains consist of the most common species found in the garbage dump (teeth and bones of domesticated species and fish bones) from the hospital associated with, and contemporary to, the convent (Fig. 1), and are listed in the Table $\mathrm{S} 2$ of the Supplementary Information. The samples mostly come from the garbage dump (sixteenth century, end of phase 2; Fig. 1) but three of the fish bones were from the soil of the convent's refectory (end of the fourteenth, beginning of the phase 2; Fig. 2). Most of the fish data come from individual bones, but they are some exceptions such as the eel 


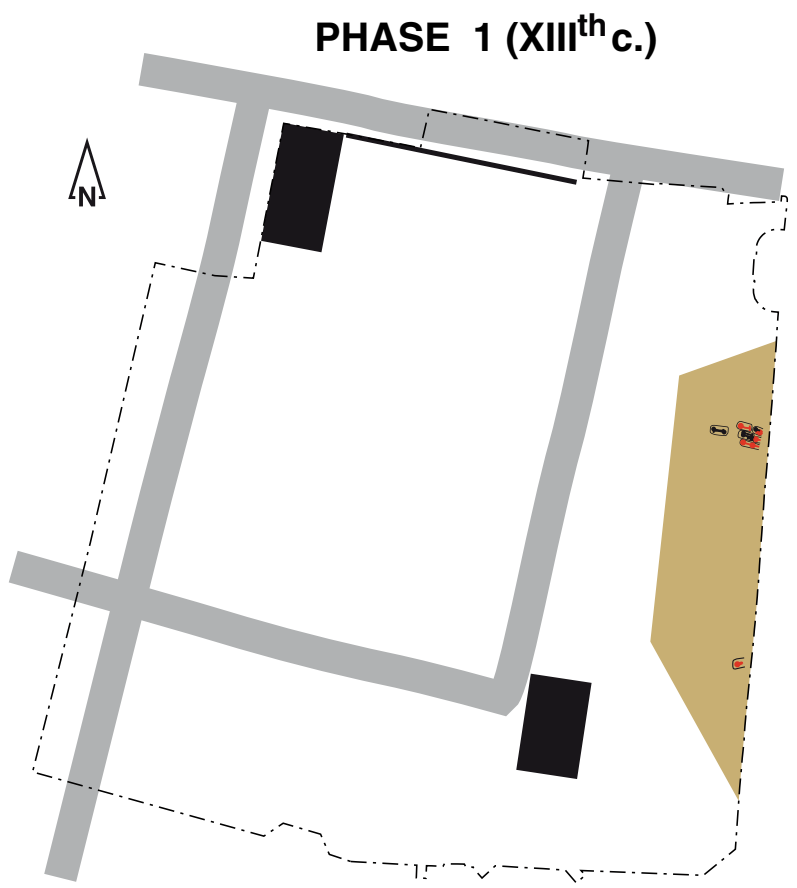

PHASE 2 (End XIVth $-X V I^{\text {th }} C$.)

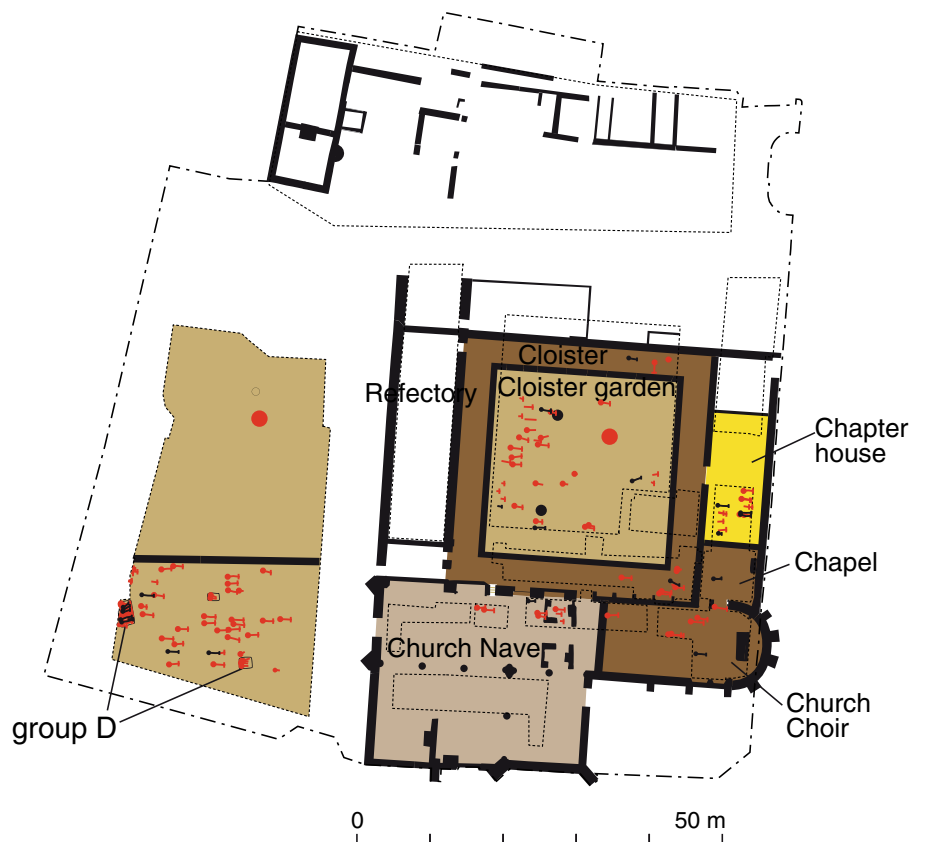

PHASE $3\left(X V I I^{\text {th }}-X V I I^{\text {th }} \mathrm{C}.\right)$

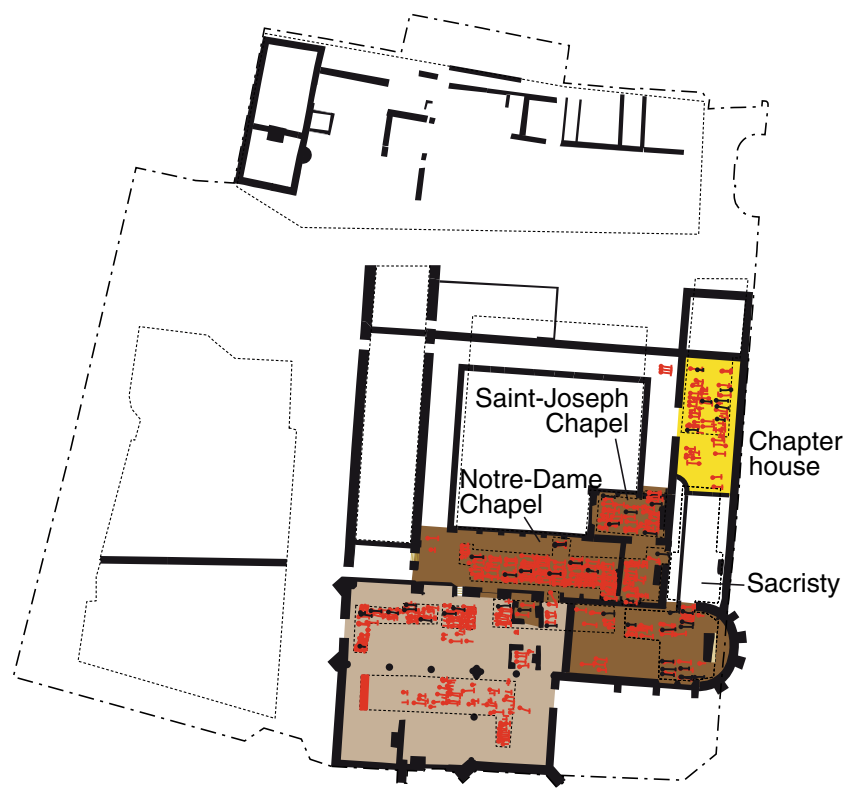

$$
\begin{aligned}
& \text { - } \text { area of the study } \\
& \text { area of the dig } \\
& \text { - path } \\
& \text { - bulding and mansonry } \\
& \text { - group A } \\
& - \text { group B } \\
& - \text { group B' } \\
& - \text { group C } \\
& \text { - grave } \\
& \text { - grave tested } \\
& \text { - secondary grave }
\end{aligned}
$$

Fig. 2 Evolution of the convent structure and location of the burials from the thirteenth to the eighteenth centuries

(Supplementary Information). A previous zooarchaeological study of the garbage dump reported that the cattle, pork, and sheep/goat represent $90 \%$ of the bone remains collected by hand (Clavel 2010). Cattle is the predominant species and are present in higher proportion than what is usually observed in the North of France (Clavel 2001; Clavel and Yvinec 2010), and $50 \%$ of them were slaughtered before the age of
20 months. The majority of the sheep were slaughtered after the age of weaning. Half of the pigs were slaughtered before the age of 13 months. Contrary to the cattle and sheep, pigs were bred in yards within the city (Croix 1981). The hospital accounts mention the presence of a pen with a sow, and her piglets and a boar were fed with food leftovers (Clavel 2001). Domestic fowl and game acquisitions are also reported but to 
Table 1 Number of individuals per sex and socio-economic group for each burial phase and associated number of sampled individuals (numbers given between brackets)

\begin{tabular}{|c|c|c|c|c|c|c|c|c|}
\hline \multicolumn{9}{|c|}{ Number of individuals excavated (and sampled) } \\
\hline Age/sex & $\mathrm{J}$ & M & PM & $\mathrm{F}$ & $\mathrm{PF}$ & I & Total adult & Total \\
\hline \multicolumn{9}{|c|}{ Phase 1 (thirteenth c.) } \\
\hline $\mathrm{B}$ & $2(1)$ & $8(5)$ & 0 & 1 & 0 & 1 & $10(5)$ & $12(6)$ \\
\hline Total & $2(1)$ & $8(5)$ & 0 & 1 & 0 & 1 & $10(5)$ & $12(6)$ \\
\hline \multicolumn{9}{|c|}{ Phase 2 (end of the fourteenth-sixteenth c.) } \\
\hline A & $4(1)$ & 4 & 0 & $7(2)$ & 1 & $4(1)$ & $16(3)$ & $20(4)$ \\
\hline $\mathrm{A}^{\prime}$ & 0 & 0 & 0 & $3(1)$ & 0 & $1(1)$ & $4(2)$ & $4(2)$ \\
\hline $\mathrm{B}$ & $12(1)$ & $32(5)$ & 0 & $15(2)$ & 0 & $12(6)$ & $59(13)$ & $71(14)$ \\
\hline $\mathrm{B}^{\prime}$ & 1 & 3 & 0 & $3(1)$ & 0 & 3 & $9(1)$ & $10(1)$ \\
\hline $\mathrm{C}$ & $3(1)$ & $4(1)$ & $2(1)$ & 1 & 0 & $4(1)$ & $11(3)$ & $14(4)$ \\
\hline $\mathrm{D}$ & $3(1)$ & $26(5)$ & 0 & 0 & 0 & 3 & $29(5)$ & $32(6)$ \\
\hline Total & $22(4)$ & $66(11)$ & $2(1)$ & $23(4)$ & 1 & $23(8)$ & $115(24)$ & $137(28)$ \\
\hline \multicolumn{9}{|c|}{ Phase 3 (seventeenth-eighteenth c.) } \\
\hline A & $39(3)$ & $83(12)$ & $19(3)$ & $73(12)$ & 17 & $68(1)$ & $260(28)$ & $299(31)$ \\
\hline $\mathrm{A}^{\prime}$ & $3(1)$ & $10(2)$ & 1 & $6(4)$ & 0 & 2 & $19(6)$ & $22(7)$ \\
\hline B & $33(1)$ & $29(8)$ & 6 & $14(2)$ & 2 & $21(2)$ & 72 (12) & 105 (13) \\
\hline $\mathrm{B}^{\prime}$ & $33(1)$ & $29(8)$ & 6 & $14(2)$ & 2 & $21(2)$ & $72(12)$ & 105 (13) \\
\hline $\mathrm{C}$ & 1 & $18(5)$ & $5(1)$ & 2 & 1 & $26(1)$ & $52(7)$ & $52(7)$ \\
\hline Total & $73(4)$ & $130(25)$ & $30(4)$ & 89 (14) & 20 & 114 (4) & $383(47)$ & $456(51)$ \\
\hline \multicolumn{9}{|l|}{ Total } \\
\hline A & $43(4)$ & 87 (12) & $19(3)$ & 80 (14) & 18 & $71(2)$ & $276(31)$ & 319 (35) \\
\hline $\mathrm{A}^{\prime}$ & $3(1)$ & $10(2)$ & 1 & $9(5)$ & 0 & $3(1)$ & $23(8)$ & $26(9)$ \\
\hline B & 47 (3) & $69(18)$ & 6 & $30(4)$ & 2 & $34(8)$ & $141(30)$ & $188(33)$ \\
\hline $\mathrm{B}^{\prime}$ & $34(1)$ & $32(8)$ & 6 & $17(3)$ & 2 & $24(2)$ & 81 (13) & 115 (14) \\
\hline $\mathrm{C}$ & $4(1)$ & $22(6)$ & $7(2)$ & 3 & 1 & $29(2)$ & $62(10)$ & $66(11)$ \\
\hline $\mathrm{D}$ & $3(1)$ & $26(5)$ & 0 & 0 & 0 & 3 & $29(5)$ & $32(6)$ \\
\hline Total & $97(9)$ & $204(41)$ & $32(5)$ & $113(18)$ & 21 & 137 (12) & $508(76)$ & $605(85)$ \\
\hline
\end{tabular}

See the text for the description of the socio-economic groupings

$J$ juvenile, $I$ indeterminate, $M$ male, $P M$ probable male, $F$ female, $P$ probable female a lesser extent. In the garbage dump, the fish bones (from sieving) are abundant and mostly come from the marine environment (more than $40 \%$ ) and migratory species $(50 \%)$ (Clavel 2010). The migratory species are dominated by eels, but the allis shad can also be found. Only $10 \%$ of the marine fishes belong to the Gadidae, the taxonomic group of the cod. These proportions of migratory, marine, and freshwater fish species nearly correspond to those found in the soil of the convent's refectory (Le Cloirec 2016). The number of taxa, both in the garbage dump and in the refectory's soil, is remarkable and includes what would have been expensive species, which argues for the wealthy status of the hospital patients (Clavel 2001), the caregivers, and the Dominicans. This wealth could notably explain why the codfish is underrepresented, whereas historical writings document its substantial consumption among urban workers. Dogs and cats can be found in the garbage dump. Most of the dogs were apparently killed, possibly during culling or because their owners could not keep them within the hospital (Clavel 2010).

\section{Methods}

\section{Anthropological data and chronology}

Sex assessment was performed using the coxal bone using morphoscopic (Bruzek 2002) and morphometric methods (Murail et al. 2005). Results are given for a sex determination probability exceeding $95 \%$, but we also mentioned "probable" sex for an assessment with a probability of 80 to $94.9 \%$. When these bones were not preserved, we performed a secondary sex diagnosis using long bone measurements. Age at death was assessed using sacropelvic surface information for adults (Schmitt 2005), stages of dental development for children (Moorrees et al. 1963a, b), as well as bone maturation when dental data were inconclusive (Palkama et al. 1961; Virtama et al. 1961; Telkka et al. 1962; Birkner 1980). We used a combination of different methods (stratigraphic data, artifacts, grave pits, and radiocarbon dating) to establish the chronology of the different burials. 


\section{Collagen extraction and stable isotope analyses}

The bone and tooth samples were first cleaned by a sandblasting technique. Then, the bone samples were pretreated using the protocol described by Richards and Hedges (1999) adding an ultrafiltration step (Brown et al. 1988). The decision was later taken to radiocarbon date some of the samples. We therefore prepared the following samples with a protocol suitable for radiocarbon dating (Talamo and Richards 2011). The protocol used for each sample can be found in the Tables S2 and S3 and does not impact final C and $\mathrm{N}$ isotope ratios.

Carbon and nitrogen isotope ratios were determined in duplicates using an elemental analyzer Flash EA 2112 coupled to a Delta XP continuous flow IRMS at the Department of Human Evolution of the Max Planck Institute for Evolutionary Anthropology (Leipzig, Germany). The sulfur isotope ratios of the first bone samples were measured at the Department of Archaeology of the University of British Columbia (UBC) on a EuroVector (HekaTech, Wegberg, Germany) elemental analyzer coupled to a Delta V-plus (Thermo-Finnigan). In addition, some samples were sent to commercial labs for measurement: Isodetect (IE; Germany) for the dentine analyses and Isoanalytical (IA; UK) for the remaining bone collagen samples (Table S3). To verify the collagen quality, the elemental composition and associated atomic ratios were measured and compared to the range of wellpreserved collagen (DeNiro 1985; Van Klinken 1999; Nehlich and Richards 2009).

\section{Results}

\section{Sulfur isotope analyses}

\section{Sulfur content}

We were able to conduct $\mathrm{S}$ isotope analysis for 72 of the 81 bones and 34 of the 54 teeth we analyzed for carbon and nitrogen. The sulfur content of all the human bone collagen samples is equivalent to that of modern mammals (Supplementary Tables S3, S4, and S8). However, terrestrial animal bone collagen ( 9 samples out of 17) and some human tooth collagen samples were poorly preserved (4 out of 34 ), with $70 \%$ of the analyzed animal samples falling out of the acceptable range defined by Nehlich and Richards (2009) (Tables S2, S4, and S8). Fish bones and animal teeth were better preserved (Tables S2 and S5). The standards analyzed by the three laboratories (UBC, IA, IE) gave consistent results (Table S6). When possible, the samples were analyzed in duplicate. The standard deviation (SD) of these duplicates is acceptable for the IA and UBC data, with most of SD's being below $0.2 \%$. However, many IE duplicates had more variation. Since it seemed to us that these data were still meaningful, we chose to include them in our study, and the standard deviation for each sample is given in Fig. 3 and the Supplementary Information.

\section{Definition of the local range and identification of the migrants}

The 69 bone and 30 tooth collagen samples for which we obtained reliable $\delta^{34} \mathrm{~S}$ values correspond to 75 individuals. The $\mathrm{S}$ isotope ratios of terrestrial animal bone and tooth collagen range from $11.4 \pm 0.1$ to $16.1 \pm 0.2 \%$. The marine fish bones have $\delta^{34} \mathrm{~S}$ values extremely close to the terrestrial animals (Figs. 3 and $10 ; \delta^{34} \mathrm{~S}=12.2-19.1 \%$ o). The terrestrial local values are therefore impacted by the sea spray. The eels have a $\delta^{34} \mathrm{~S}$ value of $11.3 \%$. The small amount of collagen extracted from freshwater fish bones did not allow us to measure the associated $\mathrm{S}$ isotope ratios. The sulfur isotope results of the terrestrial animals are consistent with them having been bred in the city or in the nearby country (Croix 1981), as the S isotope ratios of their collagen represent local values. We define the local animal range based on their average $\delta^{34} \mathrm{~S}$ values $\pm 2 \mathrm{SD}$ (10.9 to $17.3 \%$ ). We defined a local range for humans, based on the animal values. Human values that fall outside of what we have defined at the local animal range can be then considered as "non-locals." The individuals exhibiting "nonlocal" tooth values then would have spent the end of their childhood or the beginning of their adolescence in another region. If these non-local values are also present in the bone collagen, then the individual did not spend more than a few years in the area before death. The distribution of individuals with values matching the local range or showing non-local values is seen in the Table S7. Among the 24 individuals for whom bone and tooth values have been measured, half of them show an isotope shift exceeding 1\%o (Fig. 3). These isotope shifts can be positive or negative, and a significant part of it is possibly related to the analytical standard deviation, sometimes quite elevated for sulfur isotopes (Supplementary Information). All nobles (female and male) and all women tested (group $2 \mathrm{~A}^{\prime}$ and $3 \mathrm{~A}^{\prime}$ ) fall into the "local" group, and all soldiers (group D) show non-local values (bones or teeth). The bones from the privileged groups also exhibited values comparable with the local range, but one individual had a non-local value, indicating a different childhood residency. Among the 75 individuals for which $\mathrm{S}$ isotope ratios have been measured in bone and/or tooth collagen, $19 \%$ have non-local values. Most (64\%) of the non-local values can be found in the chapter house and the exteriors of the convent, whereas the number of individuals excavated and analyzed in these locations was lower than that of the church (Tables S1 and S3). 

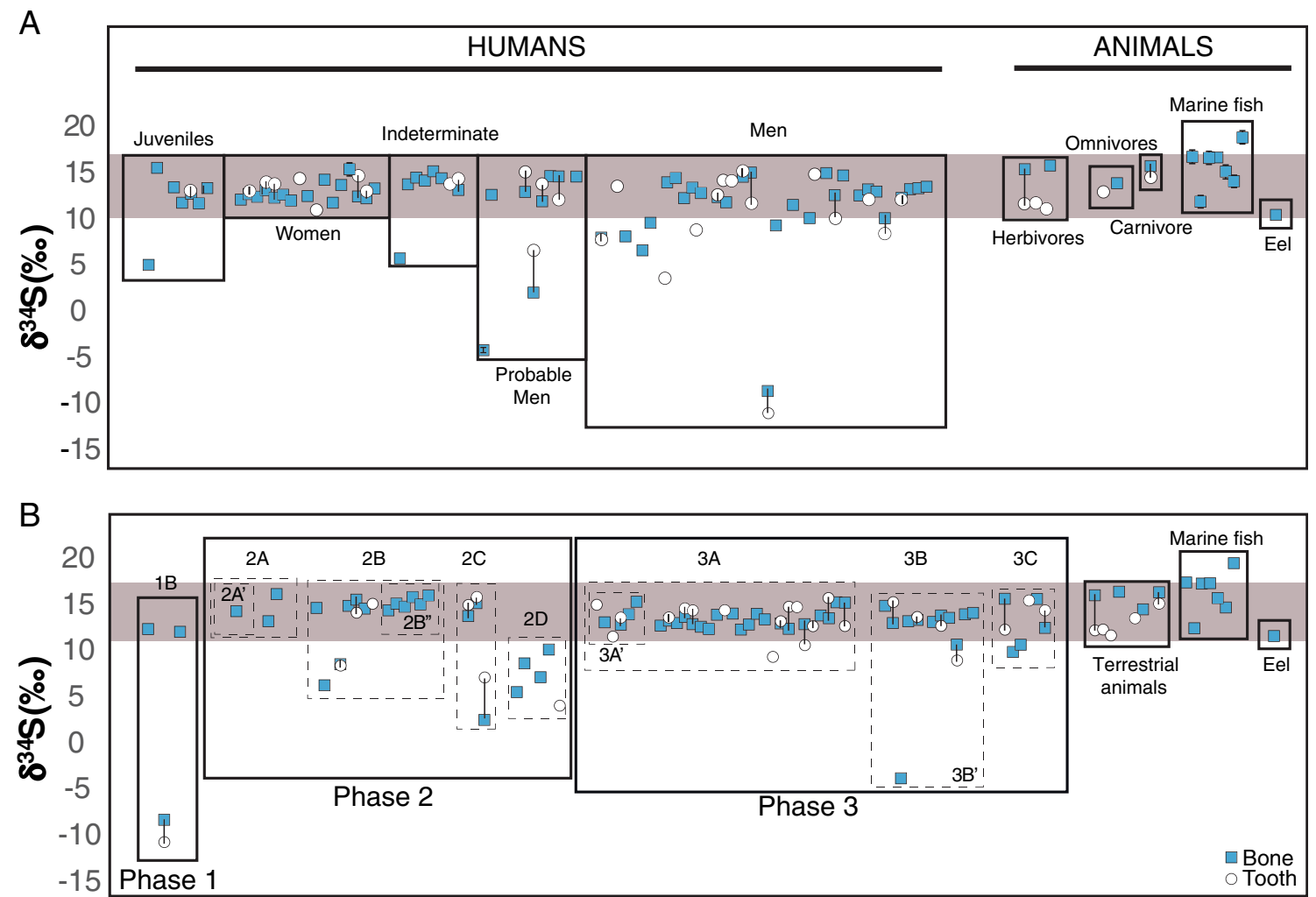

Fig. 3 Sulfur isotope compositions of the human (a grouped by gender; $\mathbf{b}$ grouped by socio-economic group) and animal bones (closed symbols) and teeth (open symbols). The grey area corresponds to the local range (see text)

\section{Carbon and nitrogen isotope analyses}

Results for $\mathrm{C}$ and $\mathrm{N}$ isotope ratios measured in animal and human bones and teeth are given for each individual in the Supplementary Information and are summarized in Table 2. All samples, which did not match quality criterion ensuring good collagen quality (more than $1 \%$ collagen yield and $\mathrm{C} / \mathrm{N}$ ratio between 2.9 and 3.6), were removed from the study (two human bone samples, seven human teeth, and four animal bones). All details on $\mathrm{C} / \mathrm{N}$ ratios, standard deviations, and collagen yields are given in the Supplementary Information.

\section{Animal bone and tooth samples}

$\delta^{13} \mathrm{C}$ ratios of the terrestrial animals indicate a diet reliant on C3-plants. $\delta^{15} \mathrm{~N}$ ratios for domestic animal bone samples tend to show higher values than what is usually observed in late medieval and early modern Europe fauna $\left(\delta^{15} \mathrm{~N}_{\text {bone }}=6.3\right.$ to $8.8 \%$ o for sheep and cattle, 9.5 to $13.9 \%$ o for the pigs; Fig. 4), except for the dog and domestic fowl. This is particularly true for five of the six piglets, which cannot be isotopically distinguished from freshwater and migratory fish (Fig. 4). The dog value falls in the herbivore range, whereas the tooth, from another dog, falls within the human range (Fig. 4). The hare and fish isotope values are similar to those previously reported in the literature (Bocherens 1991; Müldner and Richards
2005; Olsen et al. 2016). Fish $\delta^{15} \mathrm{~N}$ values are consistent with the trophic level of the various species, and the range observed in the Sainte-Anne garbage dump and the Dominican convent overlaps. The collagen of the freshwater fish was not well preserved (less than $1 \%$ of collagen for one of them, a $\mathrm{C} / \mathrm{N}$ ratio of 3.7 for the other; Fig. 5). The rabbit, usually a wild animal in medieval Northern France (Quellier 2007), shows a very high $\delta{ }^{15} \mathrm{~N}$ possibly resulting from suckling or environmental-physiological effect (Ugan and Coltrain 2011). Young rabbits were a choice dish in medieval and early modern cuisine, and their consumption was allowed during fasting days (Adamson 2004). This impact of suckling also explains the higher $\mathrm{N}$ isotope ratios observed in animal tooth collagen (Fig. 5; Supplementary Information), except for the dog tooth, as its $\delta^{13} \mathrm{C}$ value strongly differs from that of the herbivore and the other dog bones, which could reflect the occasional consumption of marine fish.

\section{Human bone and tooth samples}

The 80 bone and 48 tooth collagen samples for which we obtained reliable $\delta^{15} \mathrm{~N}$ and $\delta^{13} \mathrm{C}$ values correspond to 82 individuals. The range of $\delta^{13} \mathrm{C}$ and $\delta^{15} \mathrm{~N}$ bone and tooth data is similar to previously published data from Scandinavian or British late medieval human populations (e.g., Müldner and Richards 2005, 2007; Kjellström et al. 2009; Lamb et al. 2012; 
Table 2 Average C, N, and S isotope values of different socioeconomic groups and faunal species

\begin{tabular}{|c|c|c|c|c|c|c|c|c|c|c|}
\hline & Material & Number & $\delta^{15} \mathrm{~N}$ & SD & Number & $\delta^{13} \mathrm{C}$ & SD & Number & $\delta^{34} \mathrm{~S}$ & SD \\
\hline \multicolumn{11}{|l|}{ Animals } \\
\hline \multirow[t]{2}{*}{ Cat } & B & 1 & 11.2 & - & 1 & -19.3 & - & 1 & 16.1 & - \\
\hline & $\mathrm{T}$ & 1 & 12.4 & - & 1 & -19.2 & - & - & 14.8 & - \\
\hline \multirow[t]{2}{*}{ Dog } & B & 1 & 8.0 & - & 1 & -22.3 & - & 0 & - & - \\
\hline & $\mathrm{T}$ & 1 & 11.0 & - & 1 & -19.6 & - & 1 & 13.3 & - \\
\hline \multirow[t]{2}{*}{ Cow } & B & 2 & 7.4 & 1.6 & 2 & -21.2 & 2.3 & - & 15.7 & - \\
\hline & $\mathrm{T}$ & 1 & 8.0 & - & - & -21.6 & - & 1 & 12.0 & \\
\hline \multirow[t]{2}{*}{ Veal } & B & 1 & 7.8 & - & 1 & -22.3 & - & 1 & - & \\
\hline & $\mathrm{T}$ & 1 & 8.6 & - & 1 & -22.0 & - & 1 & 11.4 & \\
\hline $\begin{array}{l}\text { Domestic } \\
\text { fowl }\end{array}$ & B & 2 & 8.4 & 1.1 & 2 & -21.8 & 1.2 & 1 & 16.1 & - \\
\hline Piglet & B & 6 & 12.7 & 1.6 & 6 & -21.0 & 0.6 & 1 & 14.3 & 0.8 \\
\hline Eel & B & 1 & 13.3 & - & 1 & -20.8 & - & 1 & 11.3 & - \\
\hline Marine fish & B & 10 & 13.0 & 1.5 & 10 & -13.3 & 1.3 & 6 & 16.0 & 2.0 \\
\hline \multirow[t]{2}{*}{ Sheep } & B & 2 & 8.1 & 1.0 & 2 & -21.8 & 0.2 & 0 & - & - \\
\hline & $\mathrm{T}$ & 1 & 9.6 & - & - & -21.7 & - & 1 & 12.1 & - \\
\hline Game & B & 2 & 8.0 & 2.1 & 2 & -23.3 & 0.7 & - & - & - \\
\hline \multicolumn{11}{|l|}{ Humans } \\
\hline \multirow[t]{2}{*}{ 1B } & B & 6 & 11.3 & 1.6 & 7 & -19.4 & 0.4 & 3 & 5.2 & 11.7 \\
\hline & $\mathrm{T}$ & 2 & 12.2 & 1.5 & 2 & -19.1 & 0.4 & 1 & -10.7 & \\
\hline \multirow[t]{2}{*}{$2 \mathrm{~A}$} & B & 4 & 12.7 & 0.1 & 4 & -19.6 & 0.1 & 3 & 14.3 & 1.5 \\
\hline & $\mathrm{T}$ & 2 & 13.5 & 0.5 & 2 & -19.4 & 0.3 & & & \\
\hline \multirow[t]{2}{*}{$2 \mathrm{~B}$} & B & 9 & 11.3 & 0.6 & 9 & -19.9 & 0.6 & 8 & 12.9 & 3.6 \\
\hline & $\mathrm{T}$ & 6 & 12.6 & 0.7 & 6 & -19.4 & 0.4 & 3 & 12.3 & 3.6 \\
\hline \multirow[t]{2}{*}{$2 \mathrm{C}$} & B & 3 & 11.9 & 1.4 & 3 & -19.4 & 0.5 & 3 & 10.3 & 6.9 \\
\hline & $\mathrm{T}$ & 3 & 12.1 & 0.9 & 3 & -19.4 & 0.1 & 3 & 12.4 & 4.8 \\
\hline \multirow[t]{2}{*}{$2 \mathrm{D}$} & B & 5 & 11.8 & 1.9 & 5 & -19.3 & 0.8 & 5 & 7.7 & 2.0 \\
\hline & $\mathrm{T}$ & 3 & 11.7 & 1.4 & 3 & -19.2 & 0.2 & 1 & 3.9 & \\
\hline $2 \mathrm{~B}^{\prime \prime}$ & B & 5 & 12.1 & 0.4 & 5 & -19.6 & 0.3 & 5 & 14.9 & 0.4 \\
\hline \multirow[t]{2}{*}{$3 \mathrm{~A}$} & B & 30 & 13.3 & 0.9 & 30 & -19.3 & 0.4 & 28 & 13.3 & 0.9 \\
\hline & $\mathrm{T}$ & 19 & 13.4 & 1.1 & 19 & -19.2 & 0.4 & 15 & 13.1 & 1.7 \\
\hline \multirow[t]{2}{*}{$3 \mathrm{~B}$} & B & 11 & 12.4 & 0.9 & 11 & -19.4 & 0.3 & 11 & 11.6 & 3.4 \\
\hline & $\mathrm{T}$ & 9 & 13.0 & 1.1 & 9 & -19.0 & 0.4 & 4 & 9.3 & 6.7 \\
\hline \multirow[t]{2}{*}{$3 \mathrm{C}$} & B & 7 & 13.2 & 0.7 & 7 & -19.1 & 0.2 & 5 & 12.6 & 2.7 \\
\hline & $\mathrm{T}$ & 4 & 13.6 & 0.2 & 4 & -19.1 & 0.3 & 3 & 13.8 & 1.6 \\
\hline \multirow[t]{2}{*}{ ALL } & B & 80 & 12.5 & 1.2 & 80 & -19.4 & 0.4 & 70 & 12.1 & 4.3 \\
\hline & $\mathrm{T}$ & 48 & 13.0 & 1.1 & 48 & -19.2 & 0.4 & 33 & 11.4 & 5.4 \\
\hline
\end{tabular}

Isotope values are expressed in per mille

$B$ bone, $T$ tooth
Yoder 2012; van der Sluis et al. 2016), but $\delta^{15} \mathrm{~N}$ values tend to show higher values than other Western Europe regions for the same time period (e.g., Belgium: Polet and Katzenberg 2003; France: Herrscher et al. 2001; Jaouen et al. 2012; Germany: Olsen et al. 2016; Italy: Reitsema and Vercellotti 2012; Buonincontri et al. 2016; Spain: Lubritto et al. 2013; Alexander et al. 2015). The late medieval French wine maker analyzed by Bocherens (1991) however fits with the range we found in Rennes. $\delta^{13} \mathrm{C}$ values for the samples average $-19.4 \pm 0.4 \%$ o
(1 S.D.) for bones and $-19.2 \pm 0.4 \%$ for tooth. $\delta^{15} \mathrm{~N}$ values are $12.5 \pm 1.2 \%$ (1 S.D.) for bones and $13.0 \pm 1.1 \%$ o for teeth. The mean results of the analysis are presented in relation to the socio-economic group in the Table 2.

\section{Isotope differences between socio-economic groups}

Kruskal-Wallis tests indicate that $\delta^{15} \mathrm{~N}_{\text {bone }}$ values, but not $\delta^{15} \mathrm{~N}_{\text {tooth }}$ values, are strongly related to socio-economic group 


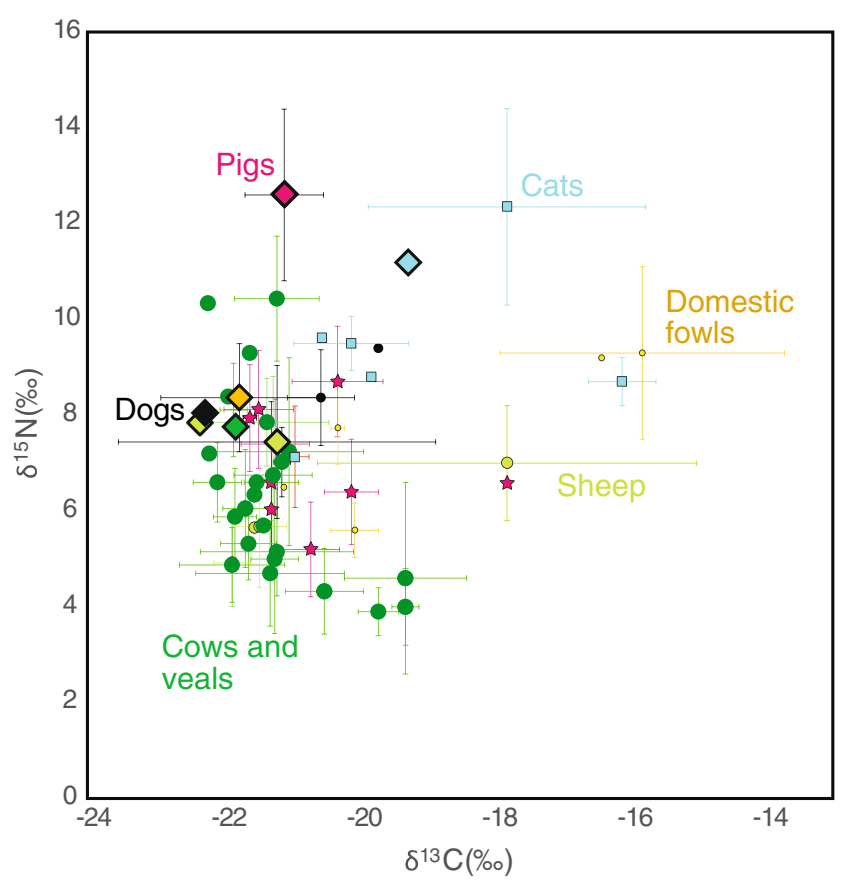

Fig. 4 Average $\mathrm{C}$ and $\mathrm{N}$ isotope ratios of terrestrial animal bones from late medieval and early modern sites. Circle symbols correspond to values from the literature (Bocherens 1991; Polet and Katzenberg 2003; Müldner and Richards 2005; Herrscher 2003; Yoder et al. 2012; Lubritto et al. 2013; Olsen et al. 2016; Quiros Castillo 2016; Alexander et al. 2015), and square symbols correspond to local values. Error bars are giving the SD for each site

$\left(\chi^{2}=31.3, p<1 \times 10^{-4}\right.$ with the $\mathrm{A}, \mathrm{B}, \mathrm{C}$, and $\mathrm{D}$ groups, $\chi^{2}=33.3, p<1 \times 10^{-3}$ with subgroups $\mathrm{A}^{\prime}, \mathrm{B}^{\prime}$, and $\mathrm{B}^{\prime \prime}$ ) even when individuals with non-local individuals are excluded. Pairwise comparisons between groups indicate that significant differences are observed between $3 \mathrm{~A}$ and $2 \mathrm{~B}\left(p<1 \times 10^{-3}\right)$. The highest $\mathrm{N}$ isotope ratios of bones $\left(\delta^{15} \mathrm{~N}_{\mathrm{bone}}=15.1 \%\right.$ o $)$ and teeth $\left(\delta^{15} \mathrm{~N}_{\text {tooth }}=15.9 \%\right.$ o can be found among the five identified nobles (group $\mathrm{A}^{\prime}$ ). The average $\delta^{13} \mathrm{C}$ and $\delta^{15} \mathrm{~N}$ values of the $\mathrm{A}^{\prime}$ group are similar to that observed in royal medieval courts in Europe (Fornaciari 2008; Lamb et al. 2014; JiménezBrobeil et al. 2016). Of note, the four individuals from the $3 \mathrm{C}$ group show higher $\delta^{15} \mathrm{~N}$ values in bones and teeth than the three individuals from the phase 2 (2C group), even though this difference does not appear significant because of the sample size (Fig. 6a). $\delta^{13} \mathrm{C}_{\text {bone }}$ values are also related to socioeconomic groups and change over time, the privileged individuals from the phase $3(3 \mathrm{~A})$ showing higher values than the individuals from the $1 \mathrm{~B}, 2 \mathrm{~B}$, and $2 \mathrm{C}$ groups $\left(\chi^{2}=16.81\right.$, $p=0.01$ without subgroups $\mathrm{A}^{\prime}, \mathrm{B}^{\prime}$, and $\left.\mathrm{B}^{\prime \prime}\right)$. When the three main burial location groups are considered (church, chapter house, and exteriors; Figs. 2 and 7), it appears that individuals buried in the exteriors of the convent (groups B, B", and D) have significantly lower $\delta^{13} \mathrm{C}_{\text {bone }}$ and $\delta^{15} \mathrm{~N}_{\text {bone values than }}$ those buried in the church (groups $\mathrm{A}, \mathrm{A}^{\prime}$, and $\mathrm{B}^{\prime} ; p=0.04$ for $\delta^{13} \mathrm{C}_{\text {bone }}$ and $p<1.10^{-3}$ for $\delta^{15} \mathrm{~N}_{\text {bone }}$ ) and in the chapter house (group C, $p=0.007$ for $\delta^{13} \mathrm{C}_{\mathrm{bone}}, p=0.016$ for $\delta^{15} \mathrm{~N}_{\text {bone }}$ ). The patterns observed in bones are similar in teeth-albeit less clear-for $\delta^{15} \mathrm{~N}_{\text {teeth }}$ values but do not appear for $\delta^{13} \mathrm{C}_{\text {teeth }}$ values.

\section{Isotope differences between bones and teeth}

$\mathrm{C}$ and $\mathrm{N}$ isotope ratios of M2 and M3 teeth roots (respectively formed between the ages of 7-16 and 12-25 years old) do not differ. The $\delta^{15} \mathrm{~N}_{\text {bone value is generally lower than the } \delta^{15} \mathrm{~N}_{\text {tooth }}}$ value of the same individual (Fig. 6a). This is particularly true for the group 1B, 2B, 3B', and 2D (Fig. 6b). The differences, between tooth and bone isotope values of carbon and nitrogen, positively correlates $\left(\Delta^{15} \mathrm{~N}_{\mathrm{b}-\mathrm{t}}=\delta^{15} \mathrm{~N}_{\mathrm{bone}}-\delta^{15} \mathrm{~N}_{\text {tooth }} ; \Delta^{13} \mathrm{C}_{\mathrm{b}-}\right.$
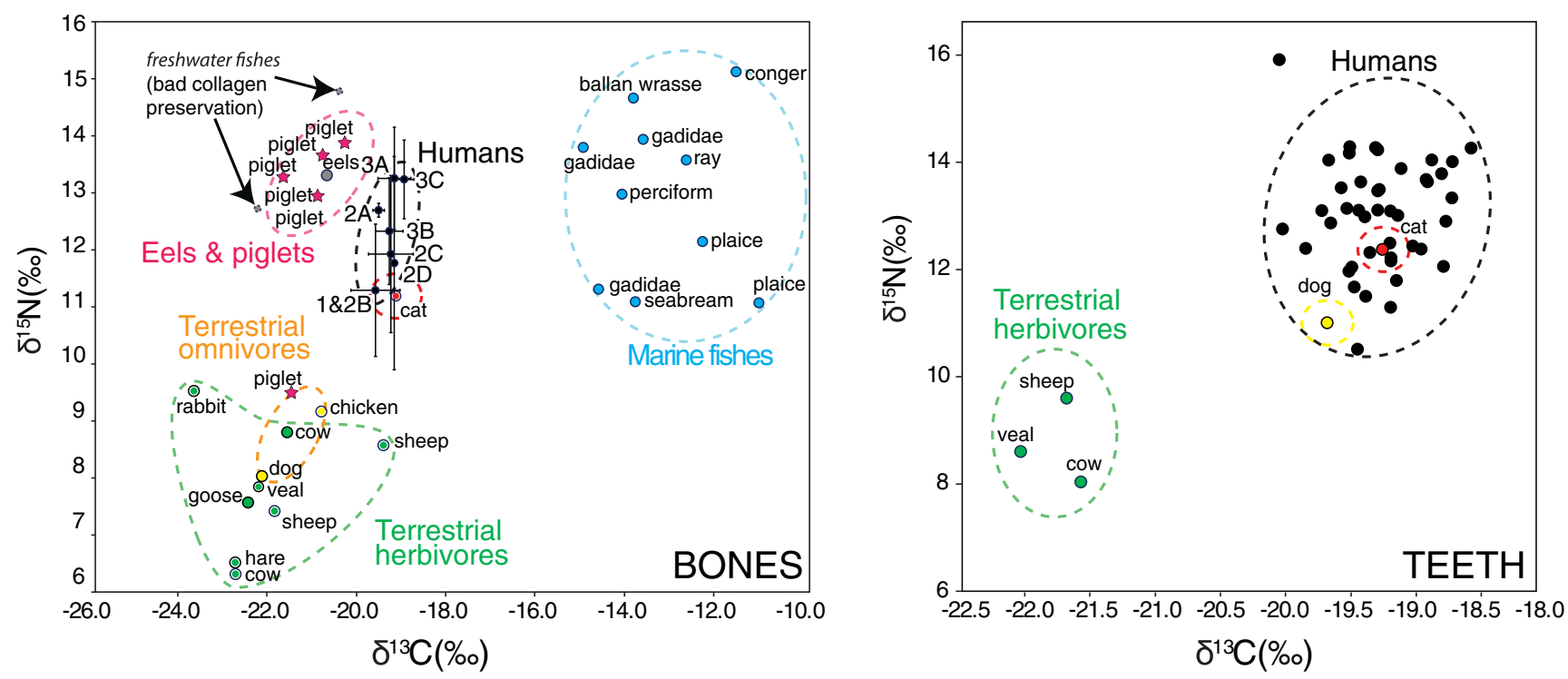

Fig. $5 \mathrm{C}$ and $\mathrm{N}$ isotope ratios of bones (on the left) and tooth collagen (on the right) of animals and humans from the Dominican convent and the SainteAnne garbage dump. SD of $\delta^{13} \mathrm{C}$ and $\delta^{15} \mathrm{~N}$ values are of 0.1 and $0.2 \%$, respectively 

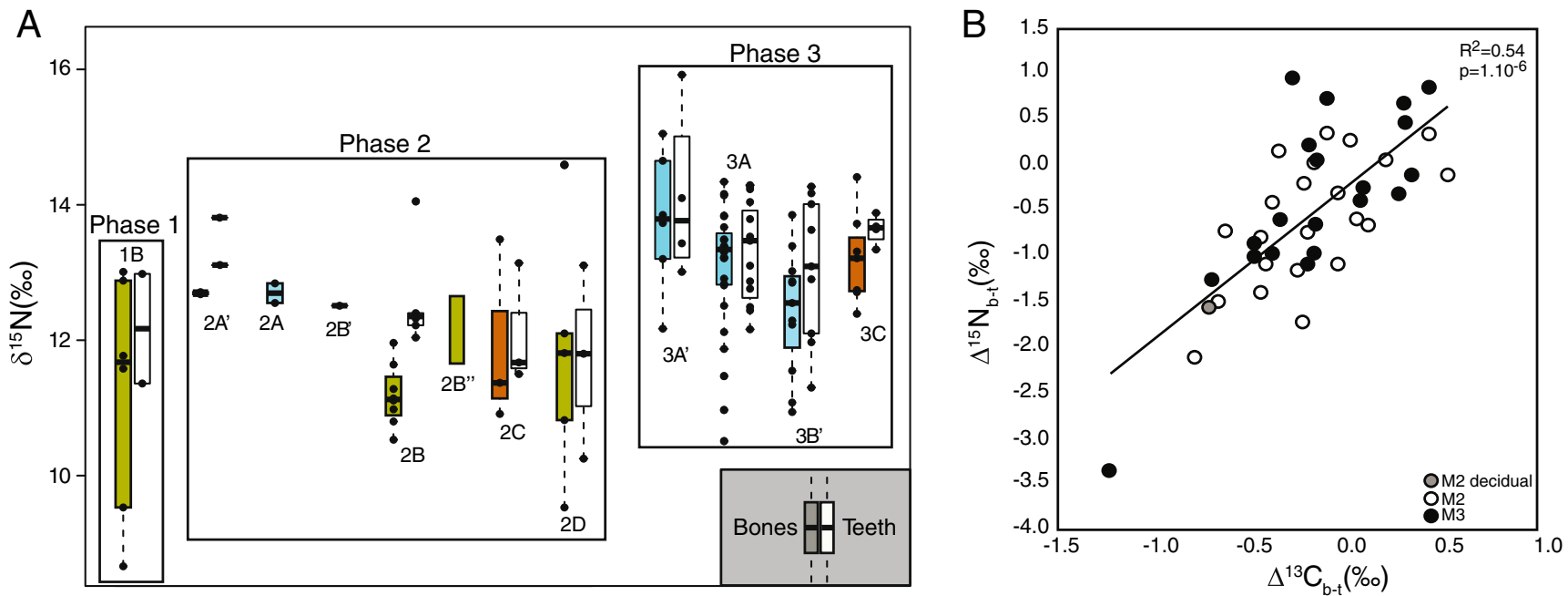

Fig. 6 Compared $\mathrm{N}$ isotope ratios in human bones and teeth. a $\mathrm{N}$ isotope ratios depending on the phase and socio-economic group. Colored box plots correspond to bone values and associated box plot to tooth values. Blue colors, privileged individuals; grey, commoners; red, ecclesiastics; green, soldiers. $\mathbf{b} \Delta^{15} \mathrm{~N}_{\text {bone-tooth }}$ and $\Delta^{13} \mathrm{C}_{\text {bone-tooth for }}$ all humans buried in the Dominican convent. M2 and M3 correspond to the molars sampled for the analyses
${ }_{t}=\delta^{13} C_{\text {bone }}-\delta^{13} C_{\text {tooth }}$; Fig. 6). There are no statistically significant differences identifiable in the mean $\mathrm{N}$ isotope ratios across the adult age range, but children and individuals who died before the age of 40 years tend to show lower values than adolescent and individuals who died after the age of 40 years (Supplementary Information, Fig. S1).

\section{Isotope differences between males and females}

To compare male and female values, we only considered individuals from socio-economic groups where both men and women were represented. We therefore excluded the groups $\mathrm{B}, \mathrm{C}$, and $\mathrm{D}$, that is too say, all the ecclesiastics and soldiers were not considered to avoid any bias related to different male social status. We found that, on average, $\delta{ }^{15} \mathrm{~N}_{\text {bone }}$ and $\delta{ }^{15} \mathrm{~N}_{\text {tooth }}$ female values are significantly higher than those of men ( $t$ test, $p_{\text {bone }}=0.006$ and $p_{\text {teeth }}=0.007$; Fig. 8). Individuals with non-local $\delta^{34} \mathrm{~S}$ values tend to show lower $\delta^{15} \mathrm{~N}$ values, except for one soldier that also exhibits a high $\delta^{13} \mathrm{C}$ value (Fig. 9). The $\delta^{13} \mathrm{C}_{\text {bone }}$ and $\delta^{15} \mathrm{~N}_{\text {bone }}$ values of local individuals poorly but significantly correlate $\left(r^{2}=0.34\right.$, $p<1 \times 10^{-3}$ ).

\section{Discussion}

\section{A privileged burial place for Bretons}

The $\mathrm{S}$ isotope ratios of the terrestrial animals from the SainteAnne garbage dump correspond to coastal values (Nehlich 2015). This observation can be explained by the fact that Brittany is a peninsula with an oceanic climate (Fig. 1). The absence of correlation between $\delta^{34} \mathrm{~S}$ and $\delta^{15} \mathrm{~N}$ or $\delta^{13} \mathrm{C}$ values of human bones and teeth indicates that $\mathrm{S}$ isotope variability is more related to location than marine (or freshwater) food consumption. In Rennes, being one of the most distant Breton cities from the coast $(60 \mathrm{~km}$; Fig. 1), we hypothesized that the whole region exhibits coastal $\delta^{34} \mathrm{~S}$ values. Additionally, most of the population of Brittany was concentrated in the capitals (Vannes, coastal city, Nantes- $50 \mathrm{~km}$ from the coast - and Rennes; Fig. 1) and within $15 \mathrm{~km}$ of the coast during this time period (Nières 2015). Consequently, individuals falling within the local range could originate from other Breton or coastal locations, whereas individuals who do not fit with this range are likely to originate from more inland regions in France or Europe. Interestingly, these non-local individuals are mostly soldiers (group D), people buried before the convent construction (phase 1), and ecclesiastics from the chapter house (group C). Eighty-one percent of the individuals analyzed are likely to come from Brittany, and this proportion goes up to $92 \%$ for those buried in the church, its chapels, and the cloister gallery. If the Dominican convent from Rennes was a pilgrimage place, it seems that most of the individuals that requested to be buried close to its miraculous painting lived in Brittany most of their life. Most of the nobles $(85 \%)$ we studied were buried after the annexation of Brittany to the Kingdom of France. It seems that they spent more time in Brittany - in their fiefdoms or in the capital cities - than at the royal court, since individuals living in the Parisian Basin are expected to have different $\delta^{34} \mathrm{~S}$ values. Bocherens et al. (2011) indeed documented very low $\mathrm{S}$ isotope ratios for Mesolithic animals from Noyen-sur-Seine that lived under climatic conditions similar to historical times. This assumption is consistent with historical evidence that documents: (1) 


\section{BONES}
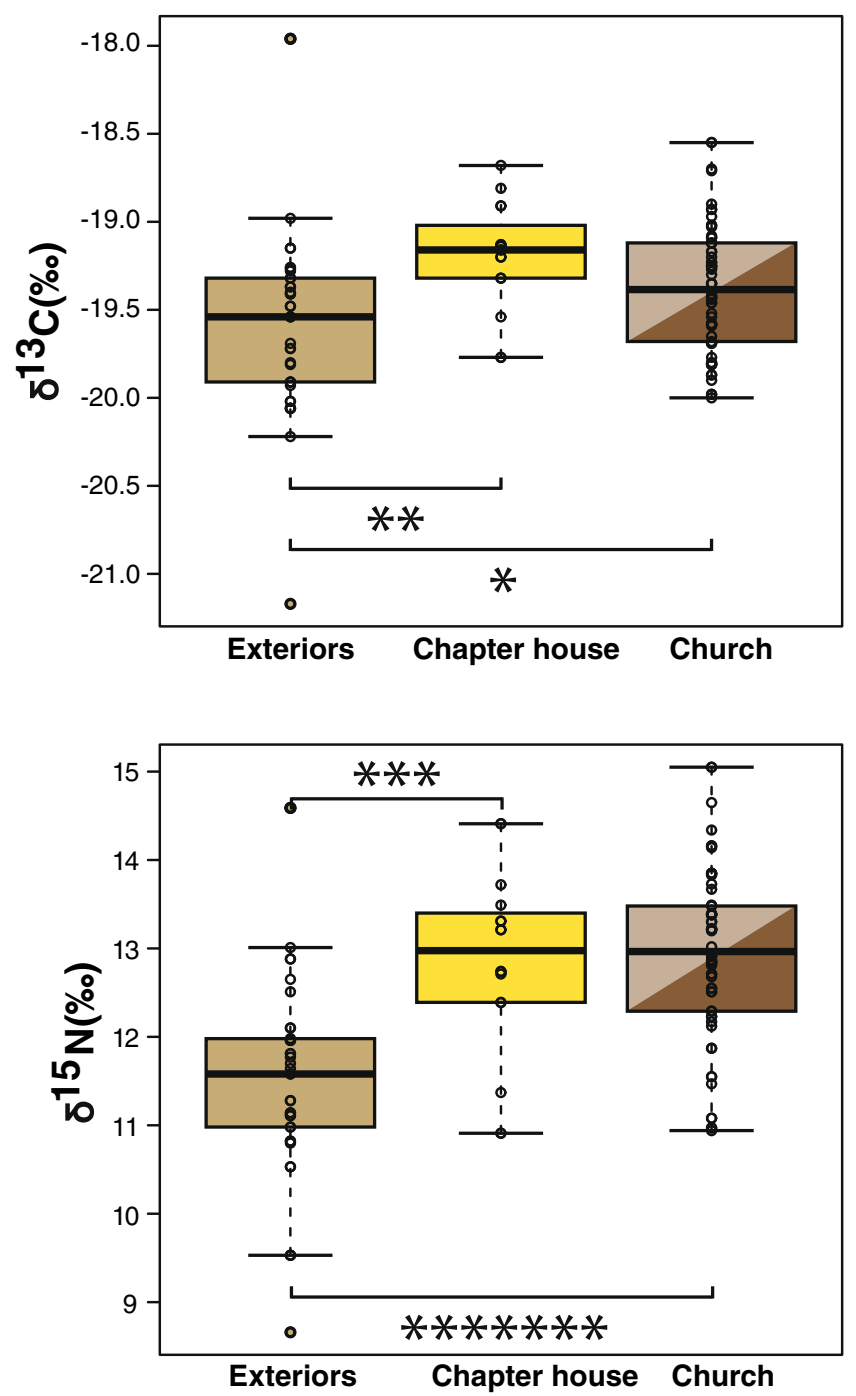

Fig. $7 \mathrm{C}$ and $\mathrm{N}$ isotope ratios in human bones and teeth depending on the burial location. Elite individuals are likely to be buried in the church, ecclesiastics in the chapter house, and commoners in the exteriors (west

the burials of parliamentary nobles in the convent, (2) the location of nobles' secondary residences in Eastern Brittany, and (3) places of birth, marriage, or death of buried individuals predominantly located in Brittany (e.g., Rennes and its neighborhood, Vannes, Nantes, Plounéventer; Le Cloirec 2016).

Non-local individuals are mostly buried during the first and second phases in mass graves (group 2D, for example). Several deadly conflicts destabilized the city in the end of the Middle Age and the beginning of the modern period, such as the capture of Rennes in 1491 and religious wars in the late sixteenth century. Foreign soldiers fought, either as enemies (e.g., the French Royal Army in 1491) or as allies (German Holy Roman Empire, British, and Spanish armies during the siege of the city and Spanish soldiers during the religion wars)

\section{TEETH}
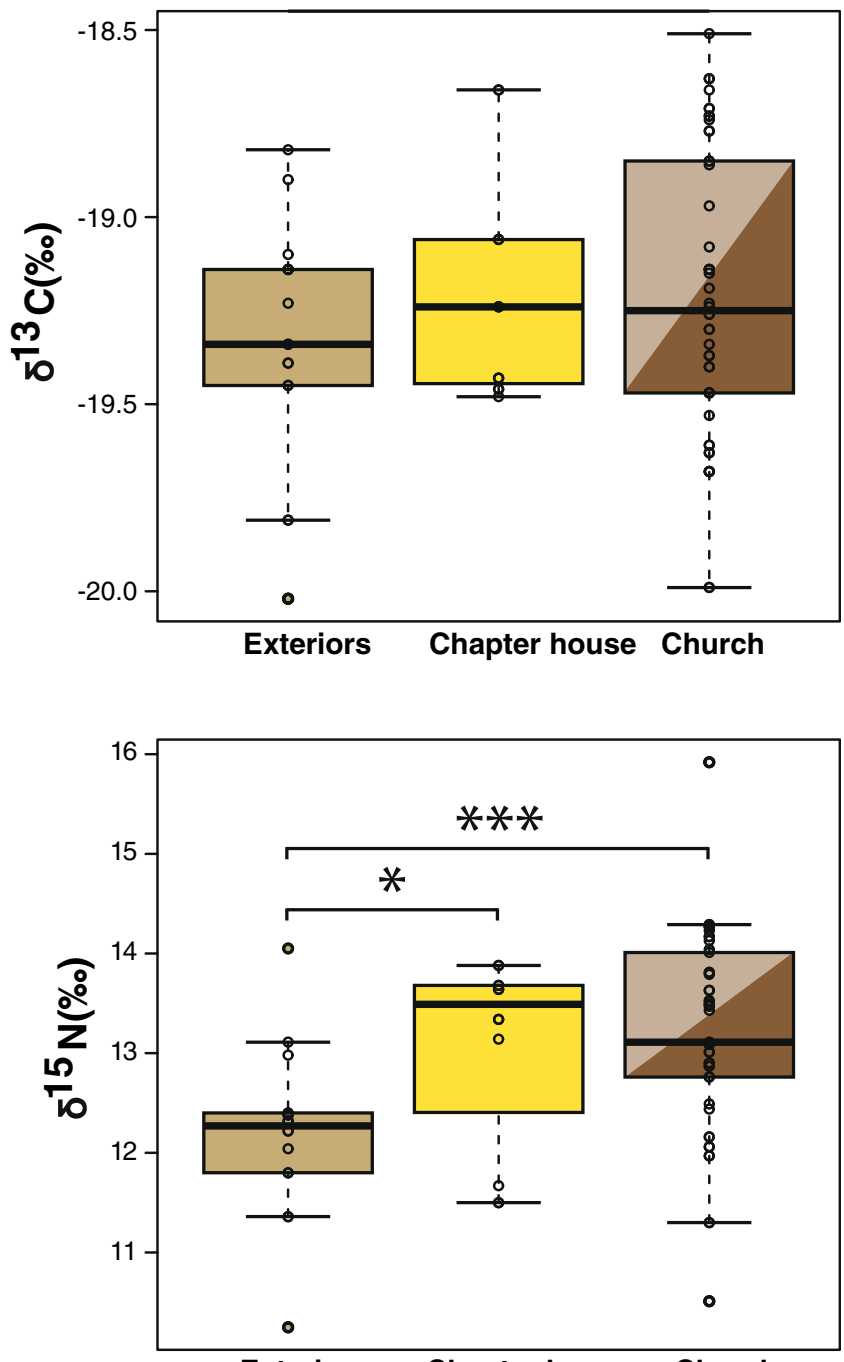

Exteriors Chapter house Church

yard, cloister, exterior). Results of the $p$ values obtained after Nemenyi tests showing differences between groups are expressed using the symbol (asterisk). $* p<0.05 ; * * p<0.005 ; * * * p<0.0005 ; * * * * * * p<5.10^{-8}$

(Croix 1993). Some of these foreign soldiers could have possibly been buried in the west yard of the Dominican convent.

\section{The importance of young animal consumption} in the aristocratic diet

The $\mathrm{C}$ and $\mathrm{N}$ isotopic ranges for bones and teeth of the individuals buried in the convent overlap with what has been previously reported in the British Isles (Müldner and Richards 2005) and indicate not only a minor contribution of marine fish into the diet but also an important consumption of migratory fish or omnivore meat. Given the low abundance of freshwater fish remains found in the garbage dump and the refectory soil, the isotope values are not likely to be explained by the consumption of these fishes. It seems that marine 


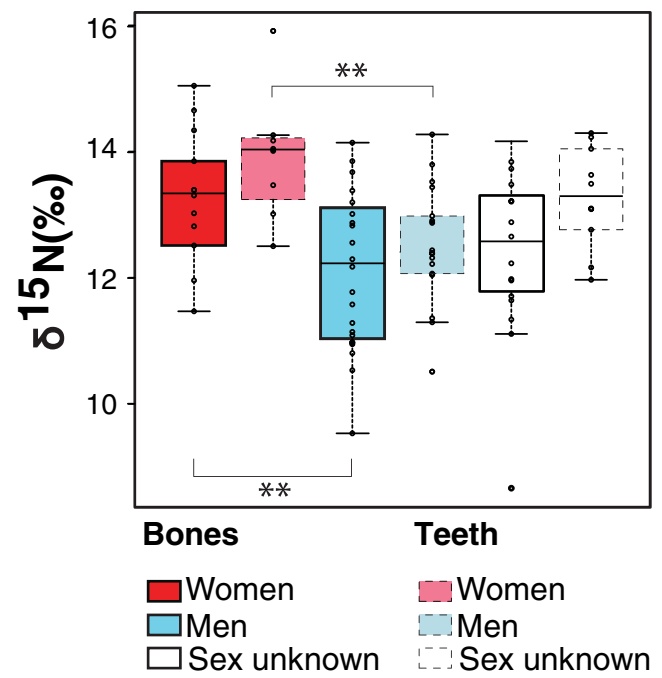

Fig. $8 \mathrm{~N}$ isotope ratios in human bones and teeth depending on the gender. Results of the $p$ values obtained after Nemenyi tests showing differences between groups are expressed using the symbol (asterisk). $* * p<0.005$

contribution in diets was more important during childhood given that the tooth values generally exhibited higher $\delta^{15} \mathrm{~N}$ and lower $\delta^{13} \mathrm{C}$ values which correlate (Fig. 6b). We noticed in Rennes higher herbivore $\delta^{15} \mathrm{~N}$ values than what is usually reported in Western Europe (Fig. 4). Interestingly, young cattle do not show higher $\delta^{15} \mathrm{~N}$ values than one of the adult cows or the sheep, which were mostly killed after weaning age (Clavel 2010). We can therefore speculate that the high $\delta^{15} \mathrm{~N}$ values of these animals could be due to the consumption of manured plants (Van Klinken et al. 2002; Fraser et al. 2011; Quiros Castillo 2016) and would partially explain the high

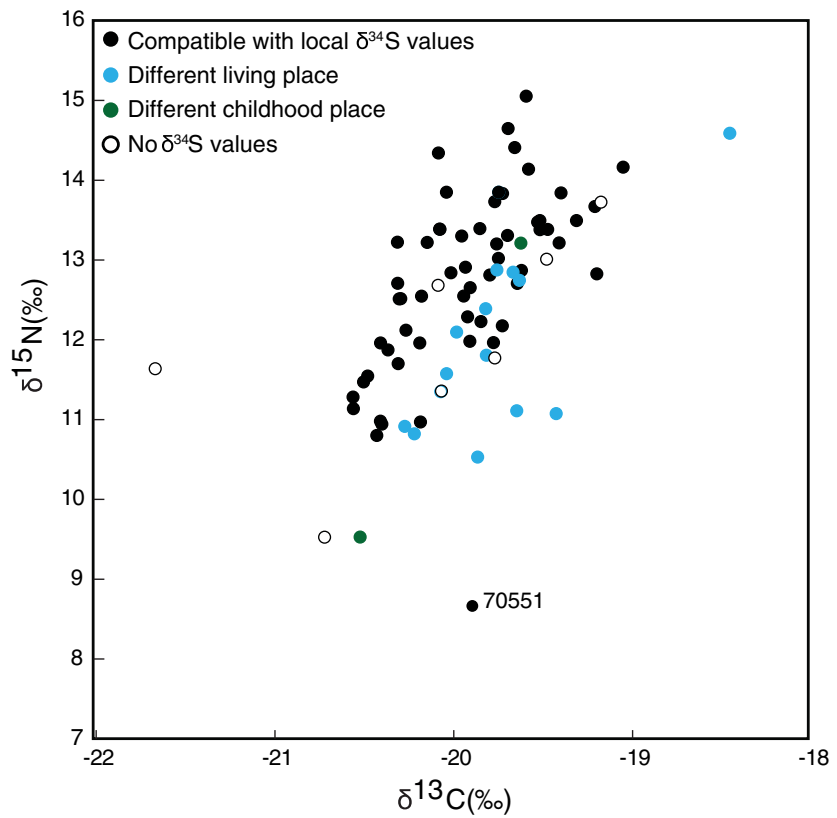

Fig. $9 \mathrm{C}$ and $\mathrm{N}$ isotope ratios of human bones. $\mathrm{SD}$ of $\delta^{13} \mathrm{C}$ and $\delta^{15} \mathrm{~N}$ values are 0.1 and $0.2 \%$, respectively $\delta{ }^{15} \mathrm{~N}$ values of the humans. With one exception, the piglets exhibit extremely high $\delta^{15} \mathrm{~N}$ values, falling into the range of freshwater fish (Fig. 5). Their $\delta^{34} \mathrm{~S}$ values also fit that of the other terrestrial animals (Fig. 9) but so do the eels - albeit the $\delta^{34} \mathrm{~S}$ eel value is much lower than the average local values (Figs. 3 and 10). One should expect similar or lower $\delta^{34} \mathrm{~S}$ for other freshwater fish (Nehlich 2015). The elevated $\delta^{15} \mathrm{~N}$ and low $\delta^{13} \mathrm{C}$ values of the humans can be explained by nonweaned animal or migratory fish consumption.

\section{Diet and social status}

Insofar as the dining table is a place where social superiority is expressed (Figeac 2013), it is expected to observe more animal protein consumption for privileged individuals. The isotope compositions however do not permit the assessment of the quality of the food eaten by the different social categories. They cannot confirm whether the privileged groups had access to the choice cuts of the animals also eaten by the other social groups. The privileged group seems to have a similar diet between the late medieval $(2 \mathrm{~A})$ and early modern periods (3A). The individuals buried in the nave $\left(3 \mathrm{~B}^{\prime}\right)$ do not significantly differ from the other individuals buried in the church, although the $\delta^{15} \mathrm{~N}$ bone values of this group are lower on average. They were also probably privileged individuals, slightly less well off than the members of the $3 \mathrm{~A}$ group. There is no burial in the exteriors of the convent in the seventeenth and eighteenth centuries. In the medieval period, the people buried in the exteriors exhibit the lowest $\delta^{15} \mathrm{~N}$ values, sometimes overlapping with the range of the local herbivores. Most of these individuals however originated from nonBreton locations.

The urban population from Rennes is supposed to have an easy access to meat products, which were cheaper than in other French regions (Croix 1981). Low $\delta^{15} \mathrm{~N}$ values such as one of the local individuals $(70,551)$ could indicate cerealbased diet of the poor individuals. Interestingly, none of the non-privileged individuals exhibit a $\delta^{13} \mathrm{C}$ values that could indicate a significant contribution of cod into the diet, contradicting historical documents (Croix 1981). There is however a clear relationship between the amount of animal products consumed in the diet and the social status estimated from the burial location and the type of burial (lead coffin, mass grave, etc.; Fig. 6; Supplementary Information).

Among the individuals buried in the chapter house, the lowest $\delta^{15} \mathrm{~N}$ values belong to individuals-including a priest — originating from other regions, according to the $\delta^{34} \mathrm{~S}$ values of bones and teeth. These individuals had a richer diet in their childhood, which could indicate the respect of their poverty vow as ecclesiastics. The local individuals tend to show similar values in their childhood $\left(\delta^{15} \mathrm{~N}_{\text {tooth }}\right)$ and adulthood $\left(\delta^{15} \mathrm{~N}_{\text {bone }}\right)$. Despite a low sample size $(n=7)$, it seems that early modern Dominicans' diet contained a higher 


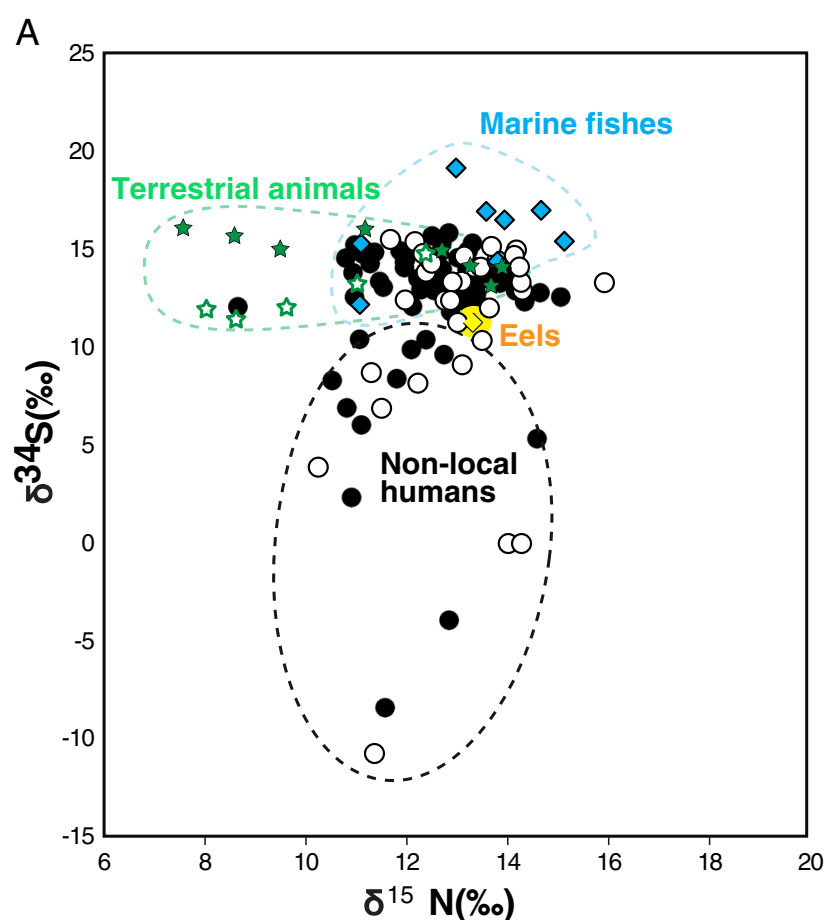

Fig. 10 Bone $\mathrm{S}$ and $\mathrm{N}$ isotope ratios (a) and $\mathrm{S}$ and $\mathrm{C}$ isotope ratios (b) of animals and humans from the Dominican convent and the Sainte-Anne garbage dump. SD of $\delta^{13} \mathrm{C}$ and $\delta^{15}-\mathrm{N}$ values are 0.1 and $0.2 \%$,

amount of young animals and/or fish than that of their medieval equivalents (Fig. 6). This trend can be seen for $\delta^{15} \mathrm{~N}$ values of bones and teeth. The early modern Dominicans have a diet similar to the privileged group, whereas the medieval friar diet is closer to that of people buried in the exterior of the convent (Fig. 5). The enrichment of the convent during the sixteenth century could therefore have led the Dominicans to feast more than fasting: among the five individuals of the convent who suffered from DISH (diffuse idiopathic skeletal hyperostosis) (Wendorf and Goldfine, 1991), two of them were buried in the chapter house.

\section{Women and juveniles' diets}

The $\delta^{15} \mathrm{~N}_{\text {tooth }}$ values generally reveal a diet with either a similar or higher amount in animal products at the end of childhood and beginning of the adolescence than during the last years before death ( $85 \%$ of the individuals for which bones and teeth have been analyzed). The decrease between $\delta^{15} \mathrm{~N}_{\text {tooth }}$ and $\delta^{15} \mathrm{~N}_{\text {bone }}$ exceeds $1 \%$ for $27 \%$ of the individuals, which are likely to have known better life conditions in their childhood than the end of their adulthood. To our knowledge, this is the first time that such a pattern is reported (e.g., Hakenbeck et al. 2010; Reitsema and Vercellotti 2012; Salazar-Garcia et al. 2014). Most of these individuals belong to the $2 \mathrm{~B}$ and the $3 \mathrm{~A}$ groups. Breton custom is somewhat original in that it is based on the practice of "noble sharing" which consists in bequeathing two thirds of its property to the

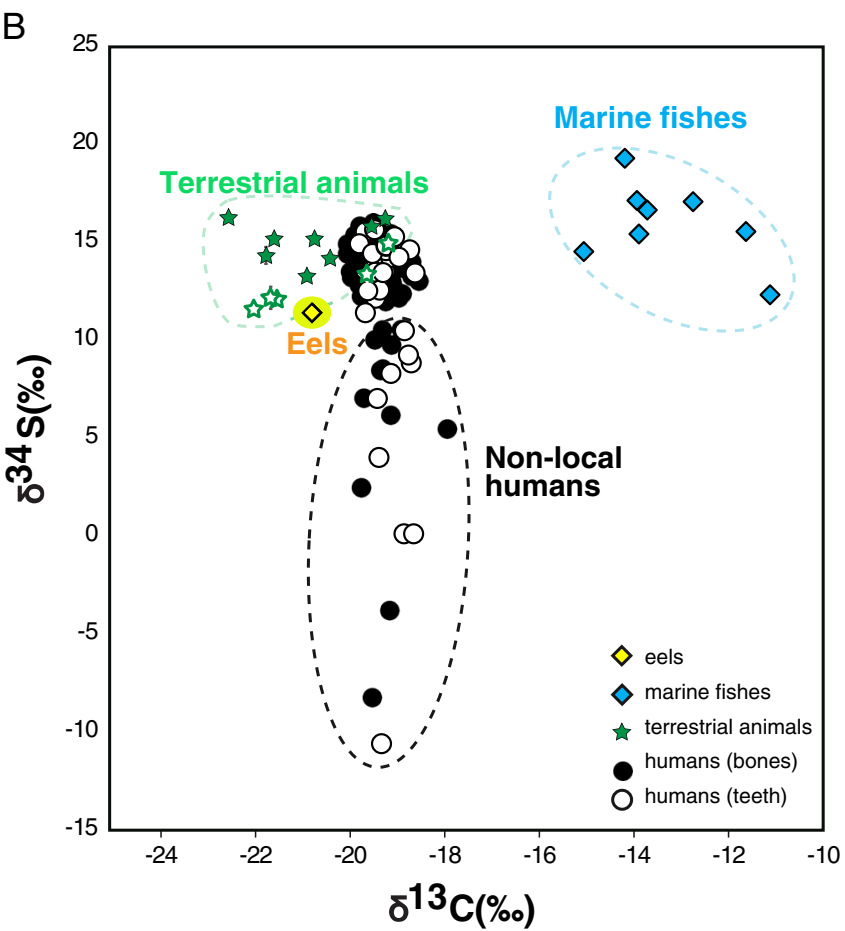

respectively. Standard deviations for the $\delta^{34} \mathrm{~S}$ values are indicated by the error bars. Close symbols, bones; open symbols, teeth

first born, without discrimination between boys or girls, the last third being divided between the other children (Chédeville and Croix 1996). The $3 \mathrm{~A}$ individuals showing such $\delta^{15} \mathrm{~N}$ depletion through life may have been the ones disadvantaged by inheritance laws.

The privileged access of men to choir and chapel burials in churches is described by the historical sources on the convent where $58 \%$ of the individuals buried in the areas corresponding of the group A are males. From archaeological sources, women (80/276) and men (87/276) are equally represented in the chapels of the Rennes Dominican convent (Le Cloirec 2016). Moreover, we noticed significantly higher $\delta^{15} \mathrm{~N}$ isotope values in female bones and teeth. This difference could either be due to a higher amount of animal proteins or a higher proportion of fish and/or young animals in their diets. The first hypothesis could indicate the burial of higher status women in the convent, possibly wealthy benefactresses such as widows with economic independence, who contributed to the clerical management and gained in recognition and emancipation. Nevertheless, young woman's isotope values do not differ from their seniors and the gender trend is more significant in the nave (group B) than in the choir or the chapels (group A). Women could also have more exceptions to fasting rules: eating more meat was for instance allowed to women in confinement (Quellier 2007). On the contrary, they could have been strictly observing the dietary rules and then eating more fish and young rabbits than men. 


\section{Conclusions}

The bone and tooth stable isotope ratios of carbon and nitrogen isotope values of commoners, ecclesiastics, and privileged individuals buried in the Dominican convent of Rennes clearly highlight differences in diet related to social class. Surprisingly, we found that the $\mathrm{C}, \mathrm{N}$, and $\mathrm{S}$ isotope compositions of suckling pigs were similar to that of the eels. We also documented quite elevated $\mathrm{N}$ isotope signature of the local terrestrial animals. This indicates that the high $\delta^{15} \mathrm{~N}$ and low $\delta^{13} \mathrm{C}$ isotope compositions of European medieval individuals could be explained by the consumption of young animals and not necessarily by an intense use of freshwater or migratory fish resources. Contrary to historical evidences, individuals belonging to the poorest socio-economic group do not have evidence of high amounts of cod fish consumption. The influence of this pilgrimage place does not seem to extend over Breton's borders, since the identified migrants mostly consist of ecclesiastics, soldiers, and individual predating the convent. Nobles buried in the convent seem to have spent their life in Brittany or coastal regions and were therefore not living at the French court. Women buried in the convent are all locals and tend to have a diet rich in animal products. Finally, we documented an increase in the amount of animal products in ecclesiastical diets during the early modern period, but that needs to be confirmed with a future study with a larger sample size.

The novel use of sulfur isotopes allowed us to further determine the origin of some of those individuals. As these studies move forward, more systematic sampling of freshwater fish is needed, as are measurements of young and adult terrestrial animals as well as the estimation of the slaughter age. The addition of results from other isotope systems (e.g., Zn) will also help to better decipher the importance of fish in medieval and early modern diets in Western Europe.

Acknowledgements Open access funding provided by Max Planck Society. We are grateful to Annabell Reiner for technical support. We would like to thank Dorothée Drucker and the two anonymous reviewers for their careful reading and suggestions, which greatly improved this paper.

Funding information We are grateful to the Max Planck Institute and the Department of Archaeology, Faculty of the Environment, Simon Fraser University for funding this study.

Open Access This article is distributed under the terms of the Creative Commons Attribution 4.0 International License (http:// creativecommons.org/licenses/by/4.0/), which permits unrestricted use, distribution, and reproduction in any medium, provided you give appropriate credit to the original author(s) and the source, provide a link to the Creative Commons license, and indicate if changes were made.

\section{References}

Adamson MW (2004) Food in medieval times. Greenwood Publishing Group, Westport
Alexander MM, Gerrard CM, Gutiérrez A, Millard AR (2015) Diet, society, and economy in late medieval Spain: stable isotope evidence from Muslims and Christians from Gandía, Valencia. Am J Phys Anthropol 156:263-273

Aubert G (2007) La Bretagne province française (1532-1789). Apogée; Presses universitaires de Rennes, Rennes

Birkner R (1980) L'image radiologique typique du squelette: Aspect normal et variantes chez l'adulte et l'enfant par médecins, étudiants et manipulateurs. Maloine, pp 564

Bocherens H (1991) Application de la biogéochimie isotopique (13C, $15 \mathrm{~N}$ ) à la détermination du régime alimentaire des populations humaines et animales durant les périodes antiques et médiévales. Arch Sci Genève 44:329-340

Bocherens H, Drucker DG, Taubald H (2011) Preservation of bone collagen sulfur isotopic compositions in an early Holocene river-bank archaeological site. Palaeogeogr Palaeoclimatol Palaeoecol 310:32-38

Bordeaux C (1992) Moi, Claude Bordeaux... Journal d'un bourgeois de Rennes au 17ème siècle. Apogée, pp 256

Brown TA, Nelson DE, Vogel JS, Southon JR (1988) Improved collagen extraction by modified Longin method. Radiocarbon 30:171-177

Bruzek J (2002) A method for visual determination of sex, using the human hip bone. Am J Phys Anthropol 117:157-168

Buonincontri MP, Pecci A, Pasquale GD, Ricci P, Lubritto C (2016) Multiproxy approach to the study of medieval food habits in Tuscany (central Italy). Archaeol Anthropol Sci:1-19

Chédeville A, Croix A (1996) La Bretagne féodale. Que Sais-Je? 2:32-48

Clavel B (2001) L'animal dans l'alimentation médiévale et moderne en France du Nord (XIIIe-XVIIe siècles). Rev Archéologique Picardie Numéro Spéc 19:9-204

Clavel B (2010) Données archéozoologiques et fouilles d'hôpitaux: l'exemple de l'hôpital Sainte Anne (Rennes, Ille-et-Vilaine). In: Les établissements hospitaliers en France du Moyen Âge au XIXe siècle. Editions Universitaires de Dijon, pp 365-379

Clavel B, Yvinec JH (2010) L'archéozoologie du Moyen Âge au début de la période moderne dans la moitié nord de la France. In: Chapelot $\mathrm{J}$ (ed) Trente d'archéologie Médiévale en France: Un bilan pour un avenir. CRAHM, Caen, pp 71-89

Colleter R, Dedouit F, Duchesne S, Mokrane F-Z, Gendrot V, Gérard P, Dabernat H, Crubézy É, Telmon N (2016) Procedures and frequencies of embalming and heart extractions in modern period in Brittany. Contribution to the evolution of ritual funerary in Europe. PLoS One 11:e0167988

Croix A (1981) La Bretagne aux 16e et 17e siècles: la vie, la mort, la foi. Maloine, pp 1571

Croix A (1993) L'âge d'or de la Bretagne: 1532-1675. éd. Ouest-France, pp 570

DeNiro MJ (1985) Postmortem preservation and alteration of in vivo bone collagen isotope ratios in relation to palaeodietary reconstruction. Nature 317:806-809

Figeac M (2013) Les noblesses de France. Du XVIe au milieu du XIXe siècle. Armand Colin, Paris, p 415

Fornaciari G (2008) Food and disease at the Renaissance courts of Naples and Florence: a paleonutritional study. Appetite 51:10-14

Fraser RA, Bogaard A, Heaton T, Charles M, Jones G, Christensen BT, Halstead P, Merbach I, Poulton PR, Sparkes D, Styring AK (2011) Manuring and stable nitrogen isotope ratios in cereals and pulses: towards a new archaeobotanical approach to the inference of land use and dietary practices. J Archaeol Sci 38:2790-2804

Fuller BT, Fuller JL, Harris DA, Hedges RE (2006) Detection of breastfeeding and weaning in modern human infants with carbon and nitrogen stable isotope ratios. Am J Phys Anthropol 129:279-293

Hakenbeck S, McManus E, Geisler H, Grupe G, O'Connell T (2010) Diet and mobility in Early Medieval Bavaria: a study of carbon and nitrogen stable isotopes. Am J Phys Anthropol 143:235-249

Herrscher E (2003) Alimentation d'une population historique: Analyse des données isotopiques de la nécropole Saint-Laurent de Grenoble 
(XIIIe-XVe siècle, France). Bull Mém Soc Anthropol Paris 15:147309

Herrscher E (2004) Comportements socioculturels liés à l'allaitement et au sevrage: le cas d'une population grenobloise sous l'Ancien Régime. Annal Fyssen, p 19

Herrscher E, Bocherens H, Valentin F, Colardelle R (2001) Comportements alimentaires au Moyen Âge à Grenoble: application de la biogéochimie isotopique à la nécropole Saint-Laurent (XIIIe-XVe siècles, Isère, France). C R Acad Sci-Ser III-Sci Vie 324:479-487

Jaouen K, Balter V, Herrscher E, Lamboux A, Telouk P, Albarède F (2012) $\mathrm{Fe}$ and $\mathrm{Cu}$ stable isotopes in archeological human bones and their relationship to sex. Am J Phys Anthropol 148:334-340

Jiménez-Brobeil SA, Laffranchi Z, Maroto RM, Sánchez FL, Huertas AD (2016) How royals feasted in the court of Pedro I of Castile: a contribution of stable isotope study to medieval history. J Archaeol Sci Rep 10:424-430

Kjellström A, Storaa J, Possnert G, Linderholm A (2009) Dietary patterns and social structures in medieval Sigtuna, Sweden, as reflected in stable isotope values in human skeletal remains. J Archaeol Sci 36: 2689-2699

Lamb AL, Melikian M, Ives R, Evans J (2012) Multi-isotope analysis of the population of the lost medieval village of Auldhame, East Lothian, Scotland. J Anal At Spectrom 27:765-777

Lamb AL, Evans JE, Buckley R, Appleby J (2014) Multi-isotope analysis demonstrates significant lifestyle changes in King Richard III. J Archaeol Sci 50:559-565

Le Cloirec G (2016) L'étude archéologique du couvent des jacobins de Rennes (35), du quartier antique à l'établissement religieux: rapport final d'opération archéologique. Cesson-Sévigné: INRAP GrandOuest, Excavation Report, pp 3835

Le Roy Ladurie E (1979) L'allaitement mercenaire en France au XVIIIe siècle. Communications 31:15-21

Lubritto C, Sirignano C, Ricci P, Passariello I, Castillo JQ (2013) Radiocarbon chronology and paleodiet studies on the medieval rural site of Zaballa (Spain): preliminary insights into the social archaeology of the site. Radiocarbon 55:e3

Martin H (1975) Les ordres mendiants en Bretagne (vers 1230-vers 1530). Pauvreté volontaire et prédication à la fin du Moyen-Âge, Rennes. Librairie C. Klincksieck, 11 rue de Lille, Paris, pp 446

Moorrees CF, Fanning EA, Hunt EE Jr (1963a) Formation and resorption of three deciduous teeth in children. Am J Phys Anthropol 21:205213

Moorrees CF, Fanning EA, Hunt EE Jr (1963b) Age variation of formation stages for ten permanent teeth. J Dent Res 42:1490-1502

Müldner G, Richards MP (2005) Fast or feast: reconstructing diet in later medieval England by stable isotope analysis. J Archaeol Sci 32:39-48

Müldner G, Richards MP (2007) Stable isotope evidence for 1500 years of human diet at the city of York, UK. Am J Phys Anthropol 133: $682-697$

Mundee M (2010) Exploring diet and society in medieval Spain: new approaches using stable isotope analysis. $\mathrm{PhD}$ dissertation, University of Durham. http://etheses.dur.ac.uk/434/

Murail P, Bruzek J, Houët F, Cunha E (2005) DSP: a tool for probabilistic sex diagnosis using worldwide variability in hip-bone measurements. Bull Mém Soc D’Anthropol Paris 3-4:167-176

Nehlich O (2015) The application of sulfur isotope analyses in archaeological research: a review. Earth-Sci Rev 142:1-17

Nehlich O, Richards MP (2009) Establishing collagen quality criteria for sulfur isotope analysis of archaeological bone collagen. Archaeol Anthropol Sci 1:59-75

Nières C (2015) Les Villes de Bretagne au XVIIIe siècle. Presses Universitaires de Rennes, Rennes, pp 612

Olsen KC, White CD, Longstaffe FJ, Rühli FJ, Warinner C, SalazarGarcía DC (2016) Isotopic anthropology of rural German medieval diet: intra-and inter-population variability. Archaeol Anthropol Sci. https://doi.org/10.1007/s12520-016-0432-y
Palkama A, Virtama P, Telkka A (1961) Estimation of stature from radiographs of long bones in children. II. Children under one year of age. Annal Med Exp Biol Fenn 40:219-222

Polet C, Katzenberg MA (2003) Reconstruction of the diet in a mediaeval monastic community from the coast of Belgium. J Archaeol Sci 30: $525-533$

Quellier F (2007) La table des français. Une histoire culturelle (XVedébut XIXe siècle) Presses Universitaires de Rennes, p 276

Quintelier K, Ervynck A, Müldner G, Neer W, Richards MP, Fuller BT (2014) Isotopic examination of links between diet, social differentiation, and DISH at the post-medieval Carmelite Friary of Aalst, Belgium. Am J Phys Anthropol 153:203-213

Quiros Castillo JA (2016) Social complexity in early medieval rural communities. Archaeopress, p 140

Reitsema LJ, Vercellotti G (2012) Stable isotope evidence for sex- and status-based variations in diet and life history at medieval Trino Vercellese, Italy. Am J Phys Anthropol 148:589-600

Richards MP, Hedges RE (1999) Stable isotope evidence for similarities in the types of marine foods used by Late Mesolithic humans at sites along the Atlantic coast of Europe. J Archaeol Sci 26:717-722

Richards MP, Fuller BT, Sponheimer M, Robinson T, Ayliffe L (2003) Sulphur isotopes in palaeodietary studies: a review and results from a controlled feeding experiment. Int J Osteoarchaeol 13(1-2):37-45

Salazar-Garcia DC, Richards MP, Nehlich O, Henry AG (2014) Dental calculus is not equivalent to bone collagen for isotope analysis: a comparison between carbon and nitrogen stable isotope analysis of bulk dental calculus, bone and dentine collagen from same individuals from the Medieval site of El Raval (Alicante, Spain). J Archaeol Sci 47:70-77

Sayle KL, Hamilton WD, Cook GT, Ascough PL, Gestsdóttir H, McGovern TH (2016) Deciphering diet and monitoring movement: multiple stable isotope analysis of the Viking Age settlement at Hofstaðir, Lake Mývatn, Iceland. Am J Phys Anthropol 160:126-136

Schmitt A (2005) Une nouvelle méthode pour estimer l'âge au décès des adultes à partir de la surface sacro-pelvienne iliaque. Bull Mém Société D'Anthropologie Paris 1-2:89-101

Schurr MR (1998) Using stable nitrogen-isotopes to study weaning behavior in past populations. World Archaeol 30:327-342

van der Sluis LG, Hollund HI, Kars H, Sandvik PU, Denham SD (2016) A palaeodietary investigation of a multi-period churchyard in Stavanger, Norway, using stable isotope analysis $(\mathrm{C}, \mathrm{N}, \mathrm{H}, \mathrm{S})$ on bone collagen. J Archaeol Sci Rep 9:120-133

Talamo S, Richards M (2011) A comparison of bone pretreatment methods for AMS dating of samples $>30,000$ BP. Radiocarbon 53: 443-449

Telkka A, Palkama A, Virtama P (1962) Estimation of stature from radiographs of long bones in children. Ann med exp et biol Fenniae 40:91-96

Ugan A, Coltrain J (2011) Variation in collagen stable nitrogen values in black-tailed jackrabbits (Lepus californicus) in relation to smallscale differences in climate, soil, and topography. J Archaeol Sci 38:1417-1429

Van Klinken GJ (1999) Bone collagen quality indicators for palaeodietary and radiocarbon measurements. J Archaeol Sci 26:687-695

Van Klinken GJ, Richards MP, Hedges BE (2002) An overview of causes for stable isotopic variations in past European human populations: environmental, ecophysiological, and cultural effects. In: Biogeochemical approaches to paleodietary analysis. Springer, pp 39-63

Virtama P, Kiviluoto R, Palkama A, Telkka A (1961) Estimation of stature from radiographs of long bones in children. III. Children aged from ten to fifteen. Ann med exp et biol Fenniae 40:283-285

Vovelle M (2000) La mort et l'Occident de 1300 à nos jours. Gallimard, Paris

Wendorf M, Goldfine IR (1991) Archaeology of NIDDM. Diabetes 40: $161-165$

Yoder C (2012) Let them eat cake? Status-based differences in diet in medieval Denmark. J Archaeol Sci 39:1183-1193 